\title{
Protein crop production at the northern margin of farming: to boost, or not to boost
}

\author{
Pirjo Peltonen-Sainio and Jarkko K. Niemi \\ MTT Agrifood Research Finland, Plant Production Research, Fl-31600 Jokioinen, Finland \\ and Economic Research, Latokartanonkaari 9, Fl-00790 Helsinki, Finland \\ e-mail: pirjo.peltonen-sainio@mtt.fi
}

\begin{abstract}
Global changes in food demand resulting from population growth and more meat-intensive diets require an increase in global protein crop production, not least as climate change and increasing scarcity of fresh water could restrict future production. In contrast to many other regions, in Finland climate change could open new opportunities through enabling more diverse cropping systems. It is justified to re-enquire whether the extent and intensity of protein crop production are optimized, resources are used efficiently and sustainably, cropping systems are built to be resilient and whether ecological services that protein crops provide are utilized appropriately. This paper aims to analyze in a descriptive manner the biological grounds for sustainable intensification of protein crop production in Finland. Production security is considered by evaluating the effects of and likelihood for constraints typical for northern conditions, examining historical and recent crop failures and estimating ecosystem services that more extensive introduction of protein crops potentially provide for northern cropping systems now and in a changing climate. There is an evident potential to expand protein crop production sustainably to a couple of times its current area. In general, variability in protein yields tends to be higher for protein crops than spring cereals. Nevertheless, protein yield variability was not necessarily systematically higher for Finland, when compared with other European regions, as it was for cereals. Protein crops provide significant ecological services that further support their expanded production. By this means protein self-sufficiency remains unrealistic, but increased production of protein crops can be achieved. The expansion of rapeseed and legumes areas also seems to be economically feasible. From the economic viewpoint, an increase in domestic protein supply requires that farmers have economic incentives to a) cultivate protein-rich crops instead of cereals, and b) use them as animal feed instead of imported sources of protein. Environmental sustainability is an argument to justify economic support for protein-rich crops and thus increase their cultivation.
\end{abstract}

Key words: Climate change, crop failure, crop rotation, ecosystem service, faba bean, food security, northern growing conditions, pea, protein, rapeseed, self-sufficiency, variability

\section{Introduction}

Europe is highly dependent on imported crop-derived feed protein, particularly soybean [Glycine max (L.) Merr.]. Europe produces only $2 \%$ of its soybean consumption although soybeans are amontg the most important crops worldwide with considerable unexplored potential (Masuda and Goldsmith 2009, Hartman et al. 2011). Overall, protein self-sufficiency in Europe averages $30 \%$, whereas in Finland during recent years it has been $\sim 25 \%$ at most. In the northernmost European growing regions, represented by Finland, alternatives for crop based protein production are more limited than elsewhere in Europe (Peltonen-Sainio et al. 2011a, 2011b). Hence, one may ask whether it would be feasible to increase the production of protein crops.

If production and consumption of protein are balanced, the industry is less dependent on fluctuations in worldwide production and prices of feed protein. Low self-sufficiency does not, however, necessarily reduce economic or environmental sustainability, because the utilisation of agricultural resources may be globally more efficient when some regions import a part of the resources they consume. During normal times it can be even more effective to rely on international trade rather than to produce most of the protein domestically. In this paper we examine possibilities to increase protein crop production. We use historical data and studies projecting future changes to elaborate the constraints and possibilities of protein crop production. Risks associated with the cultivation can, however, be larger at the farm level, because then extreme yields are averaged out by the law of large numbers. We focus on systemic events which affect yields, cultivation or economic returns on large number of farms. Hence, the focus is on the possibilities to cultivate protein crops in general in Finland, or in parts of it.

Field pea (Pisum sativum L.) and faba bean (Vicia faba L.) are potentially the most protein-rich leguminous seed crops adapted to northern growing conditions, while turnip rape (Brassica rapa L.) and oilseed rape (B. napus L.) 
are oil crops that produce high-quality protein as a valuable parallel product. Also cereals have considerable capacity to produce protein that can be enhanced further (Peltonen-Sainio et al. 2011b, 2012). However, full-scale use of hidden potential of cereals and rapeseeds requires investments in the bio-ethanol industry, which in turn provides protein-rich distillers' concentrate for feed use. Biofuel policies are expected to increase the supply of distillers' grains and protein-rich meals, and to reduce their prices in the world (e.g. OECD-FAO 2011, Fapri 2011).

As a northern speciality, spring sown cereals dominate over overwintering types by covering $99 \%$ of the cereal area in Finland. Spring wheat (Triticum aestivum L.), barley (Hordeum vulgare L.) and oat (Avena sativa L.) are together grown on about $50 \%$ of arable land in Finland. Dairy production, and thereby grasslands, are concentrated in central and northern parts of Finland, where they diversify cropping systems (Peltonen-Sainio et al. 2012). Domestic protein is better available for cattle than for monogastric animals, as grass silage, a major component in cattle diet, may contain even up to $23 \%$ of protein with a typical range of $12-23 \%$. The challenges in monograstric animals' protein feeding can also be seen as related to use of imported soybean protein in industrial feed mixtures: soybean meal contributes only $10 \%$ of protein in cattle, but $40-50 \%$ in pigs and poultry. According to data obtained from Information Centre of the Ministry of Agriculture and Forestry, feed mixture production of Finnish feed industry (close to 10 companies, from which two control the vast majority of market) is $600000 \mathrm{t}$ for cattle, $350000 \mathrm{t}$ for pigs and $300000 \mathrm{t}$ for poultry. These data indicate a comprehensive potential for expanding domestic protein crop production.

Progressive global changes provide justification for re-inquiring as to whether protein crop production should be adjusted to better meet the challenges by these changes. Driving forces for re-thinking include global population growth and increasing demand for food, together with rising standards of living in the highly populated regions, and the concomitant changes in food consumption towards meat-intensive diets that require more protein feed. OECD-FAO (2011) has estimated the consumption of beef, pig meat and poultry meat to increase in this decade in non-OECD countries by $25 \%, 33 \%$ and $37 \%$, respectively, and the consumption of cheese to increase by $33 \%$ in developing countries, whereas consumption growth in OECD-countries is only modest. In particular, significant increases in consumption are anticipated for population-rich countries such as India and China. As a consequence, the demand for crop-derived protein is increasing and the prices of soybean and rapeseeds are to increase, thus putting more economic pressure on countries with low protein self-sufficiency. In addition, climate change and increasing scarcity of fresh water exacerbate these global, multidimensional challenges.

To relate the claim of "re-thinking the status of protein crop production" to the northern conditions merits investigation. The effects of projected climate change are forecasted to be prominent and to proceed promptly in the northern hemisphere, especially in regions close to the Arctic (Jylhä et al. 2010). In contrast to many other regions, a warming climate in the northernmost European growing conditions may in the future allow extended and intensified crop production (Ramankutty et al. 2002, Moriondo et al. 2010). This is because climate warming induced prolongation of the exceptionally short growing season may boost total production and may again provide an altered basis for introduction, expansion and re-balancing cultivation of different crop species (Peltonen-Sainio et al. 2009a, Bindi and Olesen 2011). However, increased climate variability and higher risks of extreme events, such as increase in heat waves, drought episodes and heavy precipitation events (Meehl and Tebaldi 2004, Schär et al. 2004, Planton et al. 2008), may also partly, if not even fully, cancel such opportunities. Provision for prompt and comprehensive changes requires adaptation and improvements in adaptive capacity and resilience of cropping systems (Bindi and Olesen 2011, Olesen et al. 2011, Peltonen-Sainio 2012).

In recent decades, advances in food production, processing and trade have substantially strengthened food availability, stability, access and utilization (von Braun 2009). Ideally, in a certain region such crops are produced which combine market competitiveness with efficient resource use and low and/or manageable production risks. International trade provides supplementary commodities that are produced less than used in that region. Throughout the modern age, agricultural production has been regulated, subsidized and governed. One can question whether northern European crop production in its present state is expedient and well in balance, whether resources are used sustainably and efficiently, whether cropping systems are resilient and optimized when taking into account ecological services that different crops and systems offer, and whether present choices take sufficiently into account the need for short- and long-term adaptation to climate change. In such considerations it is essential to keep in mind the significance of food as the source of life, in sustaining society and its security, but also that food security is a complex socio-political concept borne of much more than cultivation (von Braun 2009, Fullbrook 2010). 
Due to major changes in the production environment it is important to re-evaluate the crop protein production in northern conditions. This paper aims to analyze whether there are biological grounds for sustainable intensification of protein crop production and by this means diversification of cropping systems under northern growing conditions (Finland case), and if so, what policies could to promote such a goal. This work considers production security through reference to effects of, and likelihood for constraints that are typical under northern conditions. Moreover, past crop failures and major fluctuations in crop production are considered and the effects of increased production on ecosystem services of northern cropping systems are estimated.

\section{Climatic constraints cause substantial production uncertainty}

Finland is the northernmost agricultural region in which seed crops are produced on a large-scale; currently 1.1 million hectares, averaging $50 \%$ of total arable land. Diversified field crop production is possible at such high latitudes of $60-65^{\circ} \mathrm{N}$ due to the Gulf Stream, which together with its northern extension, the North Atlantic Drift, is a powerful, warm and swift Atlantic Ocean current that originates in the Gulf of Mexico and influences the climate of the west coast of Europe. Therefore, northern European temperatures during the growing season are typically higher than elsewhere at comparable latitudes.

At high latitudes long day conditions markedly enhance rate of development of many crops, enabling their maturation and harvest within a short season. Various climatic constraints to seed crop production (Table 1) challenge production security in such northern regions: e.g., harsh and variable winter conditions, short period for successful spring sowing after snow melt and soil drying, short growing season and prompt changes towards growth under non-favorable autumn conditions (high precipitation, lowered temperatures, night frost, steep decline in light intensity) (Mukula and Rantanen 1987, 1989a, 1989b, 1989c, 1989d, 1989e, Peltonen-Sainio et al. 2009b, 2011c). Also early summer drought typically interferes with formation of yield potential in grain and seed crops (PeltonenSainio et al. 2011d, Rajala et al. 2011). During recent decades (Trnka et al. 2011), there have been $\geq 50 \%$ more growth-favoring days, $\geq 65 \%$ higher effective annual global radiation and at least six times more suitable days for spring sowing in other environmental zones of Europe than in the Boreal zone, which Finland represents. In addition, the Boreal zone is characterized by an exceptionally late date for the last frost but many dry, growth-limiting days in mid-summer (Trnka et al. 2011).

The short growing season, with development enhancing long days and relatively high temperatures during the early growth period, results in a combination of conditions that cause limited compensation capacity for even temporary, stressful conditions (Peltonen-Sainio et al. 2009c). This means that unfavorable conditions during the early growth period can be only negligibly compensated for at later stages. An example is long day induced inhibition of tillering in spring cereals (Peltonen-Sainio et al. 2009d): grain yield produced by lateral tillers is modest compared with that of main shoots, ranging from $13 \%$ and $15 \%$ in oat and wheat to $20 \%$ in six-row barley and $64 \%$ in two-row barley. Low tillering increases costs due to use of approximately double the seeding rate used elsewhere in Europe. In the case of failures in main shoot growth caused by climatic constraints, delayed tillering may occur if conditions become more favorable. However, these tillers do not necessarily mature by harvest time and their contribution to yield remains marginal. The ability of cereals, rapeseed and pea to compensate for low yield and grain or seed number per square meter through increased grain or seed weight is also limited (Peltonen-Sainio et al. 2007a, Peltonen-Sainio and Jauhiainen 2008; for pea data not shown).

It is not only the typical climatic constraints of the northern growing conditions that are responsible for low mean yields per hectare per se, but also substantial fluctuation in conditions, together with extreme events (Venäläinen et al. 2007) represent a challenge to northern agriculture (Peltonen-Sainio et al. 2009e, 2009c). A comprehensive modeling exercise with regional, long-term climatic datasets (Venäläinen et al. 2007) revealed foundations for current differences in regional cropping intensities through characterizing how regions differ in general growing conditions, likelihood for weather conditions harming crop growth and manifestation of extreme events (Table 2). As an example, risk of early season frost is evident in Finland, particularly in the northern parts of the country. This risk challenges rapeseed and pea in particular when compared with cereals and faba bean (Table 1). A contrary constraint to frost is represented by heat waves in May, close to sowing and seedling emergence. Such heatwaves occur at least every tenth year and they often result in poor plant stand establishment. Furthermore, during the period of the most intensive growth, severe drought ( $<10 \mathrm{~mm}$ accumulated precipitation), lasting 35-55 days, interferes with crop growth at least once in ten years, while heavy rains (39-55 $\mathrm{mm}$ per day) that cause lodging and/ or flooding occur once every tenth year. According to a dataset of the Finnish Meteorological Institute, records of one day precipitation are 88, 118, 198 and $151 \mathrm{~mm}$ for May, June, July and August and they were experienced in 1988, 1973, 1944 and 2004, respectively. 


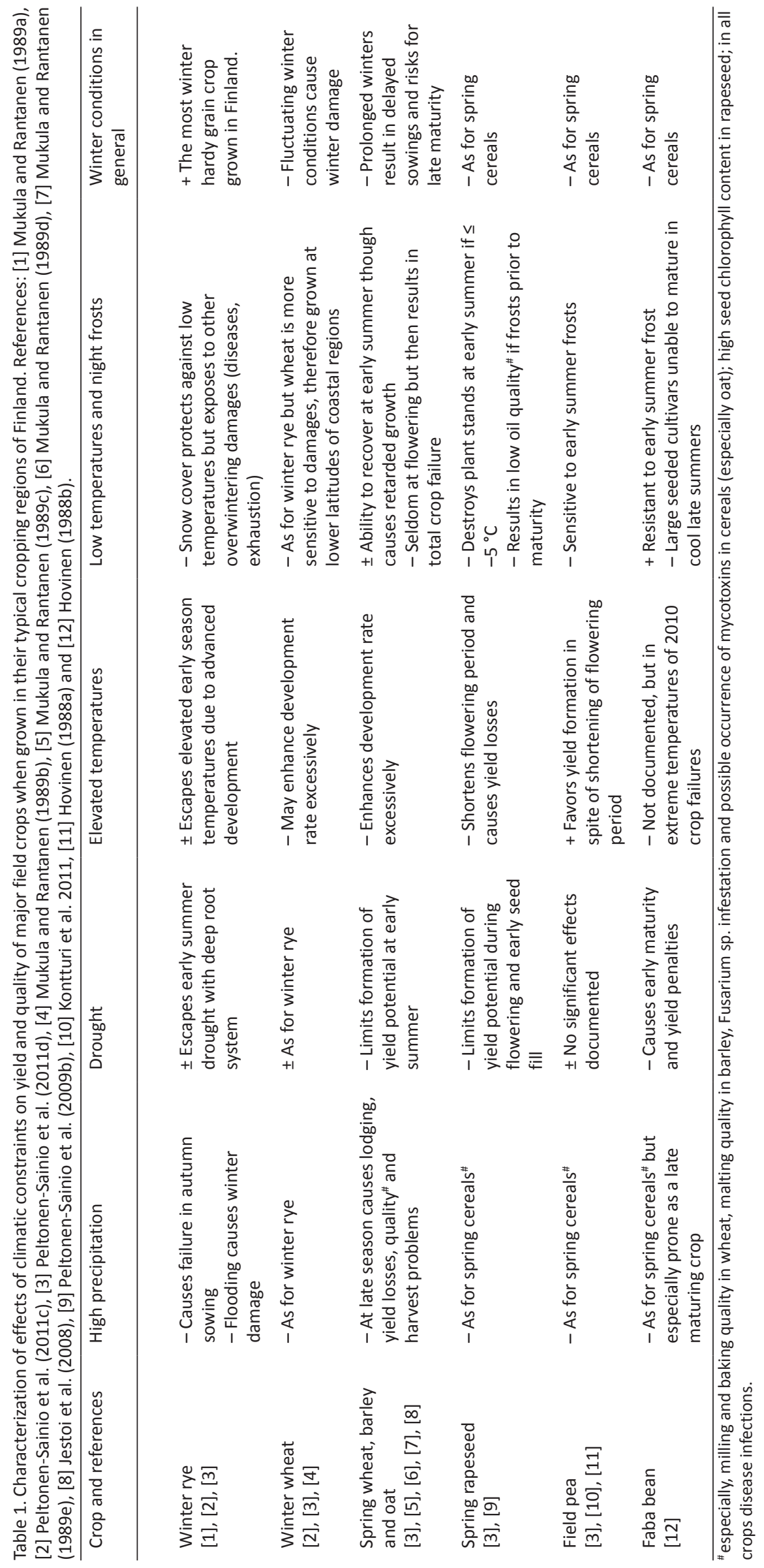


Table 2. Likelihood for having exceptional weather events every $10^{\text {th }}, 20^{\text {th }}$ and $50^{\text {th }}$ year in four locations in Finland (Venäläinen et al. 2007). For each case the $95 \%$ confidence intervals are shown (the best estimate is often close to the mean of the intervals). The provinces of Uusimaa (around Helsinki), Keski-Suomi (Jyväskylä), Pohjois-Pohjanmaa (Oulu) and Lapland (Sodankylä) contribute to the national cultivated land by $10 \%, 3 \%, 8 \%$ and $<1 \%$, respectively.

\begin{tabular}{|c|c|c|c|c|c|c|c|c|}
\hline \multirow{2}{*}{$\begin{array}{l}\text { Repeating } \\
\text { period } \\
\text { (years) }\end{array}$} & \multicolumn{2}{|c|}{$\begin{array}{l}\text { Helsinki } \\
\left(60.1^{\circ} \mathrm{N} 24.6^{\circ} \mathrm{E}\right)\end{array}$} & \multicolumn{2}{|c|}{$\begin{array}{l}\text { Jyväskylä } \\
\left(62.1^{\circ} \mathrm{N} 25.4^{\circ} \mathrm{E}\right)\end{array}$} & \multicolumn{2}{|c|}{$\begin{array}{l}\text { Oulu } \\
\left(65.0^{\circ} \mathrm{N} 25.3^{\circ} \mathrm{E}\right)\end{array}$} & \multicolumn{2}{|c|}{$\begin{array}{l}\text { Sodankylä } \\
\left(67.3^{\circ} \mathrm{N} 26.4^{\circ} \mathrm{E}\right)\end{array}$} \\
\hline & $95 \%$ & $95 \%$ & $95 \%$ & $95 \%$ & $95 \%$ & $95 \%$ & $95 \%$ & $95 \%$ \\
\hline & \multicolumn{8}{|c|}{ Minimum temperature in May $\left({ }^{\circ} \mathrm{C}\right)$} \\
\hline 10 & -2.7 & -1.4 & -8.4 & -6.9 & -7.8 & -6.5 & -15.9 & -12.8 \\
\hline 20 & -3.2 & -1.8 & -9.1 & -7.3 & -8.9 & -7.0 & -17.9 & -14.0 \\
\hline \multirow[t]{2}{*}{50} & -3.7 & -2.1 & -9.8 & -7.8 & -10.2 & -7.6 & -20.2 & -15.5 \\
\hline & \multicolumn{8}{|c|}{ Maximum temperature in May $\left({ }^{\circ} \mathrm{C}\right)$} \\
\hline 10 & 25.2 & 26.3 & 27.0 & 27.7 & 25.7 & 26.5 & 24.7 & 26.8 \\
\hline 20 & 25.7 & 27.0 & 27.3 & 28.2 & 26.1 & 27.3 & 25.4 & 27.9 \\
\hline \multirow[t]{2}{*}{50} & 26.3 & 27.7 & 27.7 & 28.8 & 26.6 & 28.3 & 26.1 & 29.2 \\
\hline & \multicolumn{8}{|c|}{ Duration of drought period in May-August with $<10 \mathrm{~mm}$ precipitation (days) } \\
\hline 10 & 39 & 53 & 32 & 39 & 38 & 51 & 33 & 42 \\
\hline 20 & 44 & 68 & 35 & 44 & 42 & 64 & 37 & 51 \\
\hline \multirow[t]{2}{*}{50} & 50 & 86 & 38 & 53 & 48 & 79 & 41 & 65 \\
\hline & \multicolumn{8}{|c|}{ Precipitation per a single day (mm) } \\
\hline 10 & 47 & 66 & 46 & 64 & 38 & 54 & 35 & 45 \\
\hline 20 & 52 & 76 & 52 & 75 & 42 & 63 & 38 & 50 \\
\hline \multirow[t]{2}{*}{50} & 60 & 92 & 61 & 92 & 50 & 77 & 42 & 57 \\
\hline & \multicolumn{8}{|c|}{ Duration of period in winter with daily minimum temperatures $\leq-20^{\circ} \mathrm{C}$ (days) } \\
\hline 10 & 4.9 & 7.6 & 9.2 & 13.2 & 10.9 & 13.9 & 13.0 & 18.1 \\
\hline 20 & 6.1 & 10.4 & 10.7 & 16.5 & 11.9 & 16.0 & 14.7 & 22.9 \\
\hline \multirow[t]{2}{*}{50} & 6.9 & 15.8 & 12.3 & 21.1 & 12.9 & 18.9 & 16.9 & 28.1 \\
\hline & \multicolumn{8}{|c|}{ Depth of snow cover at most $(\mathrm{cm})$} \\
\hline 10 & 67 & 78 & 88 & 95 & 67 & 82 & 100 & 118 \\
\hline 20 & 73 & 88 & 94 & 103 & 72 & 97 & 106 & 132 \\
\hline 50 & 79 & 102 & 99 & 113 & 79 & 117 & 114 & 153 \\
\hline
\end{tabular}

Outside the growing season, risks for long periods of extremely low daily minimum temperatures and consequent overwintering damages are prevalent. The damages are alleviated in the case that sufficient snow cover protects seedlings (Table 2). Extreme conditions challenge winter hardiness of overwintering crop per se, but may also be associated with risk of delayed sowing in spring (Table 1). Delays in sowing are often more harmful for later maturing protein crops, which further increases insecurity for their production when compared with cereals (Peltonen-Sainio et al. 2011d).

Coefficient of variation in national yield was often higher for protein crops, rapeseed and pea, than for wheat, which represents cereals in Figures 1-3. Variation in yield and changes in cropping area were often inconsistent, as also found by Peltonen-Sainio et al. (2010). For Denmark, France, Germany (western zone) and Sweden (Boreal south) wheat yields varied less than for Finland (Boreal north) and Spain (Mediterranean). On the other hand, degree of variation in yields of rapeseed in Finland was comparable to that found elsewhere in Europe, except for Spain, which is characterized by exceptional yield variability. For pea, variation was particularly high, as also concluded by Cousin (1997), and was especially so in the Nordic countries, though it was also significant for Germany. These examples indicate that when comparing with other growing regions in Europe, although Finland represents a disadvantageous exception regarding production certainty of wheat yields, the difference is not so striking as with pea yield (Figs. 1-3). 

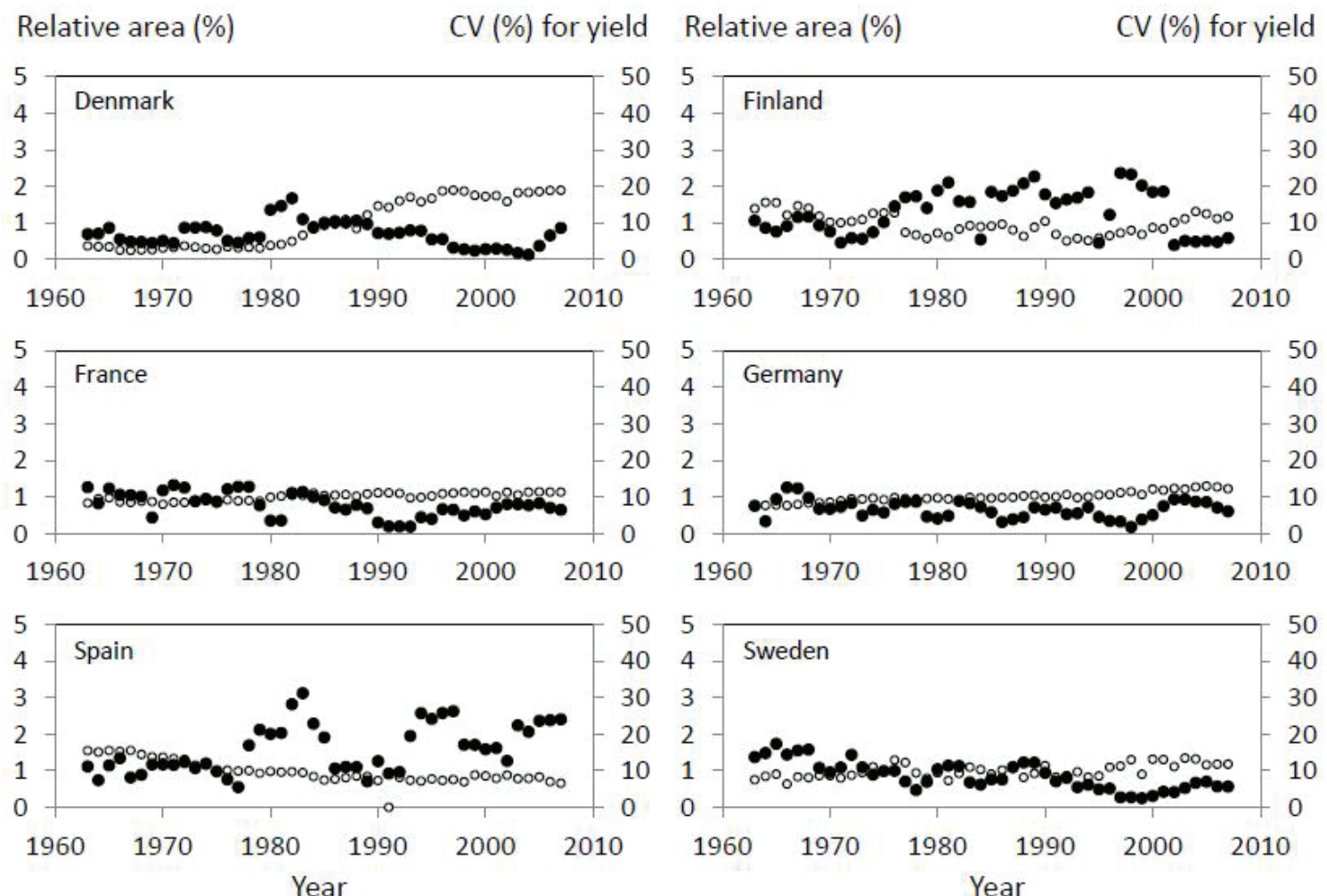

Fig. 1. Changes in national wheat production areas relative to the mean areas across the studied period are shown as open circles for 1963-2007 (left-hand axis) for Denmark, Finland, France, Germany, Spain and Sweden. Variation in coefficients of variation (CV) for yields (right-hand axis) are shown as black circles and were determined by dividing each 5 year moving average for standard deviation of yield by that for annual mean yield. Data from FAO (2011).

Relative area (\%)
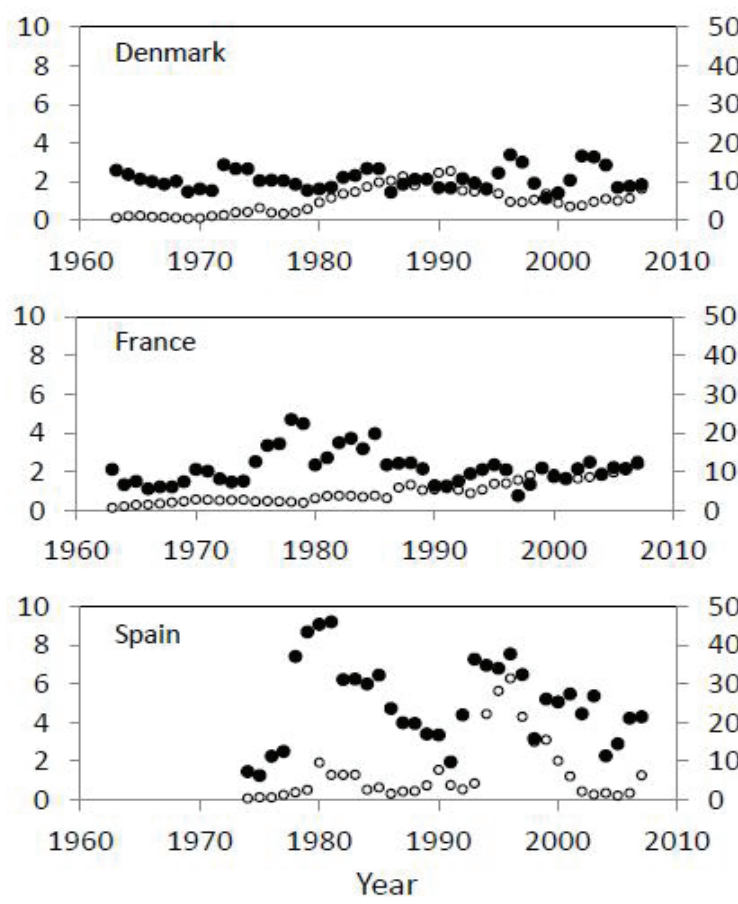

CV (\%) for yield
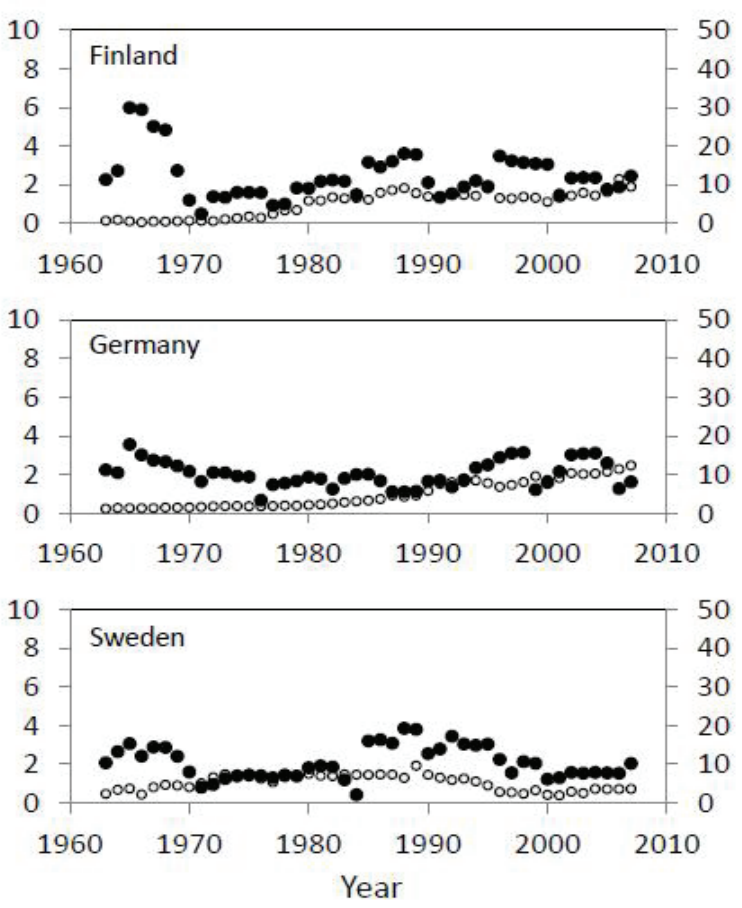

Fig. 2. Changes in national rapeseed production areas relative to the mean areas across the studied period are shown as open circles for 1963-2007 (left-hand axis) for Denmark, Finland, France, Germany, Spain and Sweden. Variation in coefficients of variation (CV) for yields (right-hand axis) are shown as black circles and were determined by dividing each 5 year moving average for standard deviation of yield by that for annual mean yield. Data from FAO (2011). 

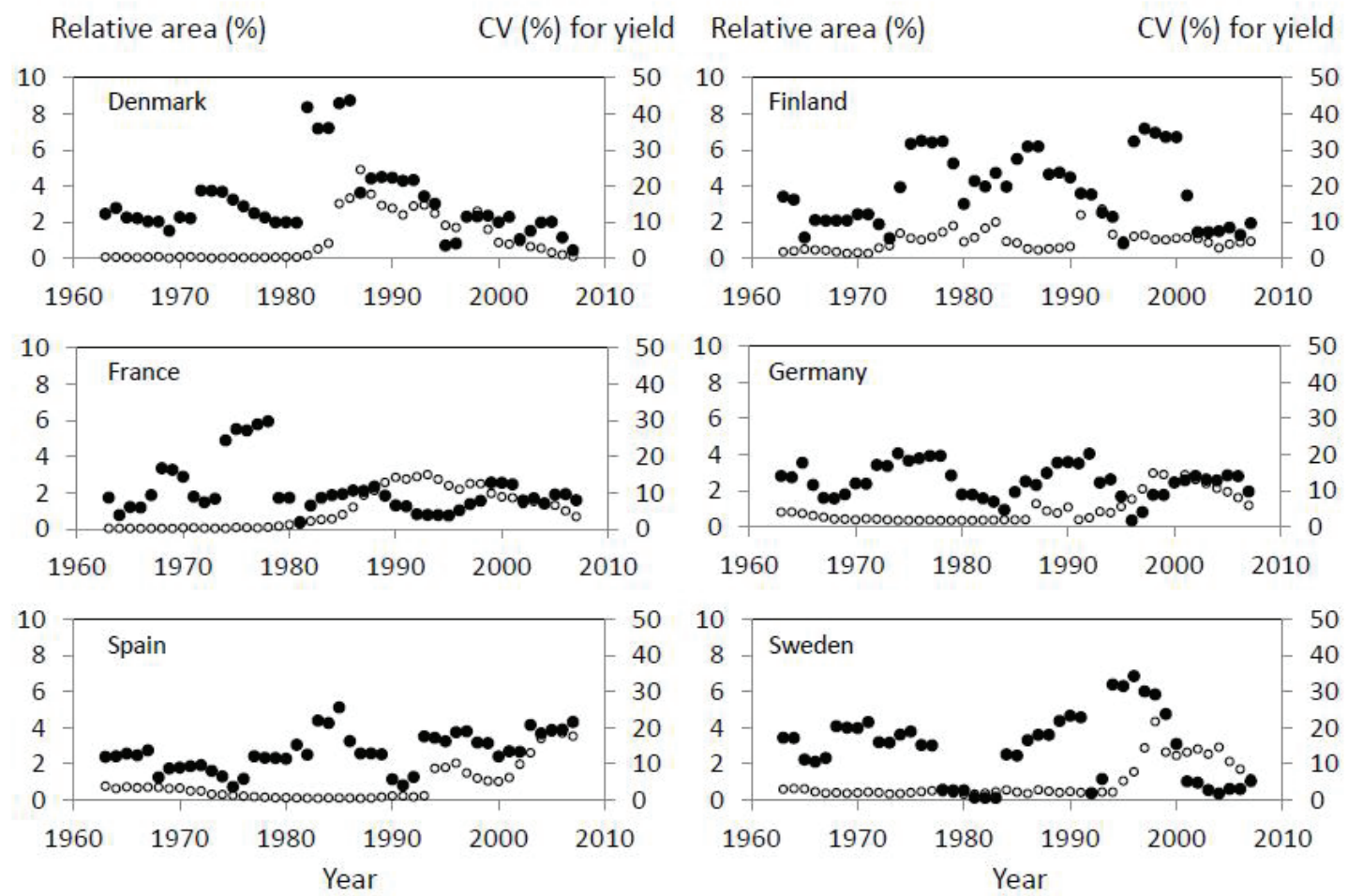

Fig. 3. Changes in national field pea production areas relative to the mean areas across the studied period are shown as open circles for 1963-2007 (left-hand axis) for Denmark, Finland, France, Germany, Spain and Sweden. Variation in coefficients of variation (CV) for yields (right-hand axis) are shown as black circles and were determined by dividing each 5 year moving average for standard deviation of yield by that for annual mean yield. Data from FAO (2011).

\section{Historical perspective on yield risks: Extreme events, famine and mortality in the past centuries and lessons learned}

In the past food security and production went hand in hand. Insecurity in crop production was caused by severe harmful climatic conditions that caused shortages of food, famine and mortality. In contrast, today they do not have marked impact on the availability of food. Climatic events that occurred in years of high mortality in Finland are typical for northern agricultural regions also today. According to Holopainen and Helama (2009), in the most unfavorable years the amount of harvested grain was less than that sown, whereas during the better years the grain harvested exceeded that sown by more than tenfold. They also estimated that during the period of preindustrial agriculture in Finland, depending on region, 37-84\% of yield variability was explained by monthly variation in growing season temperature and precipitation.

Three periods of extreme famine and resulting high mortality rates were documented in regions of present day Finland. All of them fell into the period termed the Little Ice Age, lasting from ca. 1450 to 1870 (Mann 2002, Mann et al. 1998, Mann and Bradley 1999). This was a period of climatic cooling in the northern hemisphere that occurred after a much warmer era known as the Medieval Warm Period. The first documented, large-scale and fatal crop failure in regions of present day Finland was in 1601, when a severe volcanic eruption of Huaynaputina in Peru caused abrupt cooling to spread over the northern hemisphere (Briffa et al. 1998, de Silva and Zielinski 1998). The most exceptional, negative temperature anomaly was evident for summer 1601, which is reflected in extremely weak growth of tree-rings of Scots pine (Pinus sylvestris L.) in Fennoscandia (Lindholm and Eronen 2000, Helama et al. 2005). The year 1601 was called in Finnish "olkivuosi" ("straw year") or "iso hallavuosi" ("year of extensive frosts"), while in Sweden it was characterized as the "green year" (Mukula 1981a). All these terms seem to characterize the conditions well: severe frosts likely occurred prior to maturity and according to some notes, no grain was available for harvest in certain regions of Finland. At most yields only approached $20 \%$ of normal yields. Therefore, food was substituted for by straw gruel, bark bread, roots of calla (Calla palustris L.), moss and bark of aspen (Populus tremula L.). 
The next documented period of extensive crop failure occurred in 1696-1697 and was termed "isot kuolovuodet" ("years of extensive mortality"). Severe crop failures occurred after first experiencing a couple of years of crop losses and marked food insecurity. Again, strong cooling events took place probably due to volcanic eruptions (Briffa et al. 1998). In 1695 cereal yields were only one third of the standard yields for that time, crop losses mainly resulting from severe autumn frosts (Mukula 1981b). In 1696 scarcity of seed for sowing was inevitable, sowings were markedly delayed in spring and again severe autumn frosts caused high crop losses. In spring 1697, after extensive famine, up to $30 \%$ of the Finnish population died.

The third fatal crop failure occurred in 1867-1868 and the period was referred to as the "suuret nälkävuodet" ("years of extreme famine"). Again, a couple of unfavorable growing seasons preceded the years of extreme famine. In 1866 sowings were delayed, when in Helsinki, for example, the mean temperature for May was $7^{\circ} \mathrm{C}$ lower than normal (Mukula 1981c). Cool and dry conditions occurred in 1867, sowings took place exceptionally late, and again early, severe autumn frosts destroyed the yield. Only one quarter of barley managed to mature, rye (Secale cereale L.) yields were $\sim 60 \%$ of normal and potato (Solanum tuberosum L.) $\sim 70 \%$. About $8 \%$ of the population died due to famine, but plague also spread through migration.

Lessons were learned from periods of extreme famine in Finland and many of the changes that took place clearly attempted to improve food security. One of them was diversification of agricultural systems and thereby, loosening of the dependency on solely grain crop production (Mukula 1981d). This was also warranted as soils became depleted of nutrients and their production capacity declined. By reintroducing animal husbandry more manure was available to improve soil structure and nutritional status. However, less cereal was available for human consumption and therefore, cereal imports were considered, which in turn weakened the peasants' position until extended animal husbandry gradually started to improve peasants' income again.

The structural change was enormous. Up to $40 \%$ of arable land was sown to grassland within three decades (18801910). This was, however, achieved by clearing forests and not to any significant extent at the expense of cereal production area (Mukula 1981d). By the 1950s crop rotations were further diversified, when there was a golden age for pea cultivation. This was followed by drastic reduction in the area under a pea crop (data not shown). Some signs of revival were recognized in the 1970s and 1980s that were, however, followed by decline and, in turn, rapeseed production expanded. Today rapeseed, pea and faba bean are minor crops in Finland.

During the period 1880-1910, the idea of being a self-sufficient producer of many of the agricultural commodities was abandoned. However, wars in the early $20^{\text {th }}$ century shook up the reasoning behind heavy dependence on imports, which did not solely occur in times of distress. Food security is one of the perquisites for a well-functioning modern society. When food is not secure, also security of a society is put at risk (Fullbrook 2010). Over time stockpiles of crop seeds were organized (Mukula 1981d), which is the predominant practice in Finland also today. One reason for stockpiling is the goal to have crop cultivars which are well adapted to the exceptionally short long-day, northern growing seasons and can be used for sowing.

\section{Crop failures since 1960}

Crop failures have been experienced during recent decades, including the 1960s, 1980s and 1990s (Fig. 4). During the study period, 1981, 1987, 1998 and 1999 were characterized as the years with the most extreme crop failures (Fig. 5): respectively $20 \%, 45 \%, 22 \%$ and $18 \%$ of the agriculture in terms of land area was recorded as having totally failed. Of these years, 1981, 1987 and 1998 had exceptionally cool growing seasons, while in 1999 drought interfered with crop growth. In general, crop failures have occurred on more than $5 \%$ of agricultural land every third year.

Proportion of commercially acceptable harvested yield is another measure that indicates failure in production. Regions differ in likelihood of success in production of high quality cereal and pea yields (Fig. 6). For all cereals and pea, and for most years, regions with $\geq 80 \%$ commercially acceptable yields were identified. Production of each crop was mainly located in regions characterized by a sufficiently long growing season and/or relatively low production risks. Annual means for proportion of high quality seed yields were, however, typically lower and more variable for only marginally grown pea: once every six years less than $50 \%$ of harvested pea yields were commercially acceptable, while such low mean quality was hardly ever recorded for barley and oat, and less often than every tenth year for spring and winter wheat. In general, earlier maturing winter wheat had a slightly higher proportion of high-quality yield than spring wheat, which is more prone to quality deterioration caused by abundant autumn rains. Furthermore, when such regions in which winter wheat was grown only in limited areas were excluded, risks of low quality were even lower. 

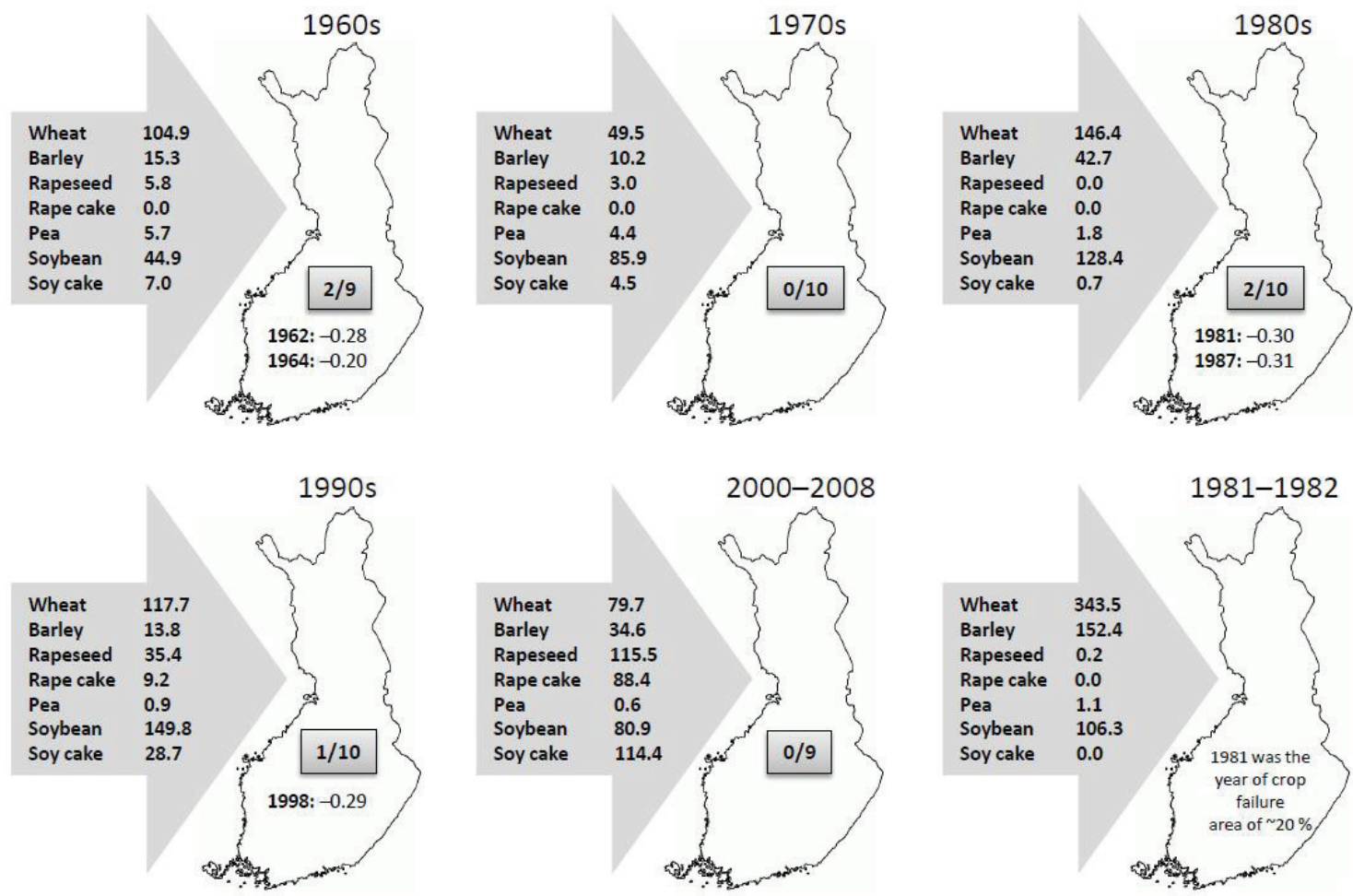

Fig. 4. Import of cereals and protein crops (million kg year-1) into Finland in different decades and as an average for 1981-1982 when cereal importation was at its highest. The occurrence of years with marked crop losses demonstrated for barley (which is an early maturing indicator crop) are shown as well as the years with relative yield difference $\geq-0.20$. Relative yield difference was determined by subtracting decadal mean for barley yield from the mean yield of a year and by dividing with the decadal mean. Data from FAO (2011).

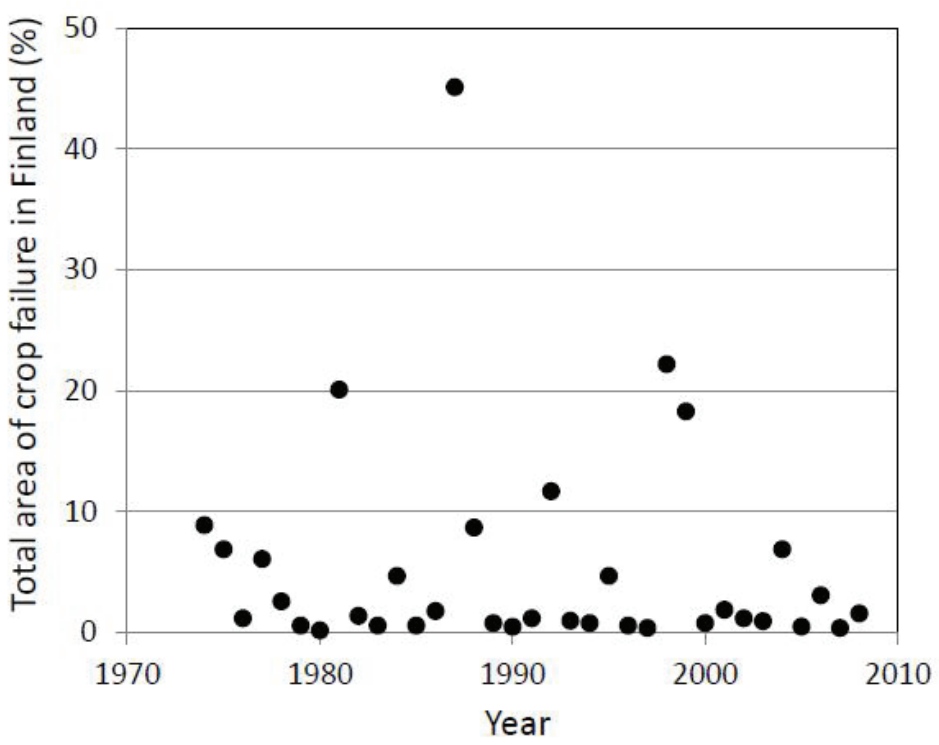

Fig. 5. Total area of crop failure compared to cultivated arable land in 1974-2008. Data from Tike (2012). 

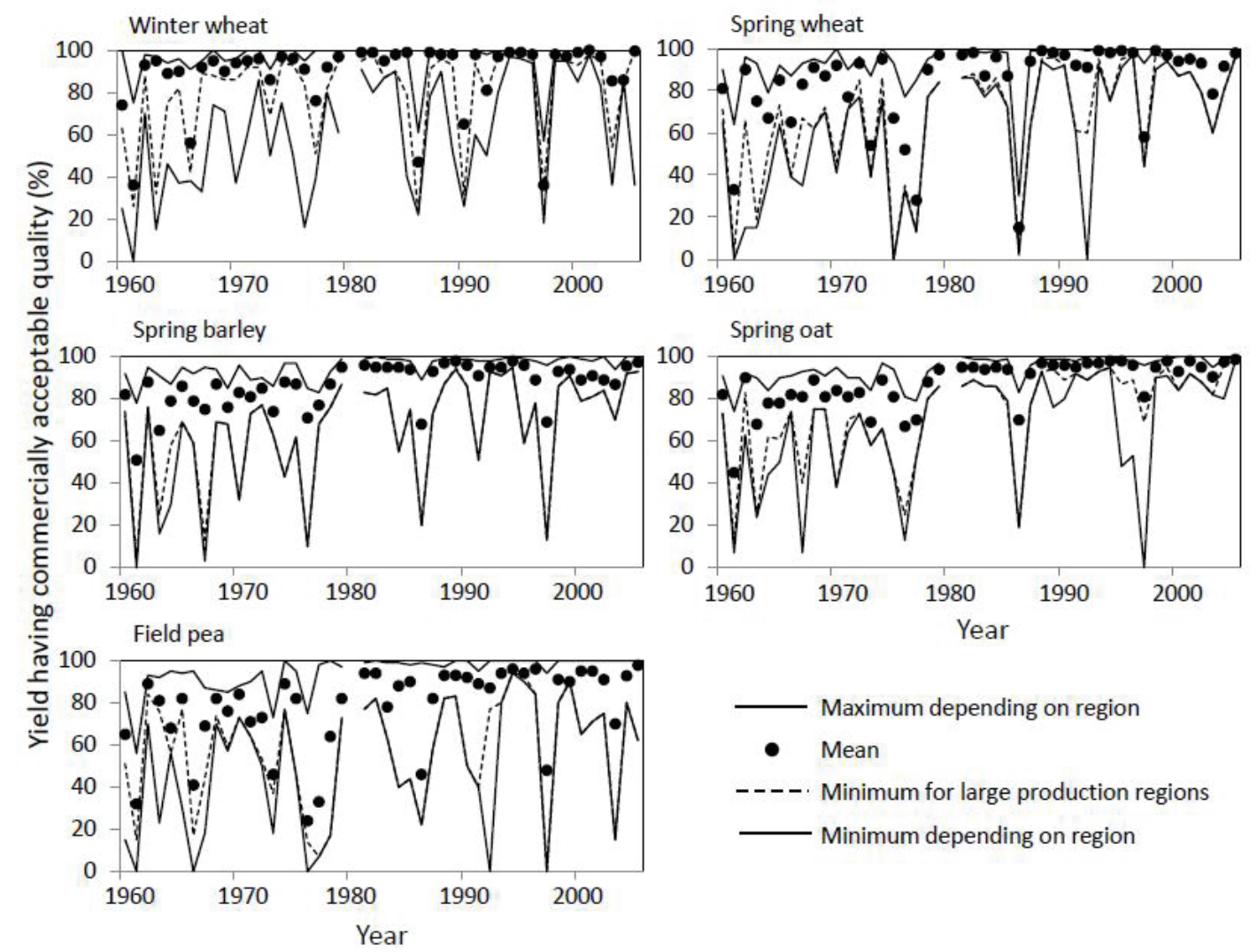

Fig. 6. Annual mean and regional range for proportion of harvested yields of winter wheat, spring wheat, barley and oat as well as field pea that was considered to be commercially acceptable in 1961-2006. Crop failure year 1987 was not included in the statistics, but it is likely that only very poor quality yield was harvested. Dashed line indicates annual regional minimum for proportion of yields of acceptable quality when only regions were included that had $\geq 1000$ hectares under cultivation of a crop, except $\geq 100$ hectares for field pea. Data from Tike (2012).

Pea failed more often than cereals to produce high quality yield (Fig. 6), which can partly be attributed to the limited cropping areas devoted to pea. Especially for legumes intercropping may provide a means for more stable production (Kontturi et al. 2011, Peltonen-Sainio et al. 2012). However, the criteria used for determination of commercial acceptability of pea yield are for human consumption. Therefore, criteria are likely to be far too rigorous for use in monitoring quality of animal feed. In fact, one could argue that quality criteria are even too harsh regarding human consumption when quality deficiencies are often only visual and are caused by pea moth (Cydia nigricana F.), for example. Pea moth is the most serious pest of pea in Finland, and a high risk of infestation is likely to accompany increase in pea cropping area (Huusela-Veistola and Jauhiainen 2006). In general, risks for yield losses caused by pests and diseases are presently moderate in the northern growing conditions. This is because complex host-pathogen and crop-pest-predator interactions as well as reproduction of pests and pathogens are influenced by weather conditions, i.e., often suppressed in northern cool climates (Hakala et al. 2011). Nevertheless, pest and disease induced risks are higher for rapeseed and legumes when compared to cereals and grass crops (Roukola and Vestberg 1978, Hannukkala 1988, Engqvist and Ahvenniemi 1997, Peltonen-Sainio et al. 2007b, Peltonen-Sainio et al. 2012). In spite of these identified differences in risks between crops in Finland, protein crops do not represent a disadvantageous exception regarding production certainty when compared with other European regions contrary to that of wheat yields (Figs 1-3).

\section{Balancing between success and failure through export and import}

Finland is an exporter of oat, barley and, at times, wheat. In all these crops export volumes tend to be higher the higher the annual total production. Clearly higher import rates for years with lower total production were recorded only in the case of wheat. Moreover, increase in rapeseed demand has likely resulted in a situation in which higher total national production is associated with higher import volumes. Hence, the question is, would it be possible to allocate more land area to protein crops instead of these exported products. In general, only wheat imports exceeded those for rapeseed into Finland. Despite low protein self-sufficiency in Finland, the role of pea as an import crop was negligible as soybean dominates import markets. 
According to decade-based assessment in the 1970s and 2000s, no marked crop failures were recorded, and less wheat was imported than in the 1960s, 1980s and 1990s that had two, two and one marked failure years, respectively (Fig. 4). However, this did not pertain to protein crops: rapeseed import volumes increased, especially in the 1990s and further so in the 2000s, while the role of pea as an imported crop dropped steadily and that of soybean increased, especially in the 1980s and 1990s. Increased imports of rapeseed during the most recent decades is not solely a result of increase in global production of rapeseed, or the capacity for rapeseed to substitute soybean in animal feeds, but also due to decline and stagnation in national rapeseed yield trend (Peltonen-Sainio et al. 2007b). Both increasing volume of monogastric animal production and public policies may also have played a role. Rapeseed production has been subsidized in the EU. Since 1992 MacSharry reform, the Common Agricultual Policy (CAP) has aimed at reducing the market prices of European agricultural products first through the use of area-based payments and later through the use of decoupled support to arable farming, thus improving the competitiveness of European rapeseed over the imported crops.

More detailed analysis was carried out to compare how import peak years for different crops were associated with changes in production capacity when compared with associated non-peak import years (Table 3). Peaks in import volumes for all cereals were associated with reduction in total production in the preceding year. Grain yields that were systematically lower per hectare in a preceding year contributed to reduction in total national production as often did smaller cropping area. Again such findings did not concern rapeseed and pea. Furthermore, according to limited information available for pea (which completely lacked for rapeseed), a low proportion of high quality seed yield was not associated with high import volumes. Only for oat, the most important export crop, were total national crop failure areas clearly higher in peak import years than in the proximal non-peak years. This was also true for oat and barley regarding proportion of high quality yields that were lower for peak than for nonpeak years (Table 3 ).

All these examples of changes in import and export volumes emphasize that due to the current low national production of protein crops compared to use, success or failure in national production does not systematically alter their import ratios or that for soybean. As protein crops are, at present, only minor crops in Finland, advances in their total production, through increase in cropping area and seed yield per hectare, need to be dramatic until fluctuations in their annual production capacities would likely have any significant effect on import ratios. Hence the question: is it realistic and if so, what policies could do?

An important question from the global sustainability viewpoint is how nutrient runoffs and greenhouse gas emissions on a global scale may be affected by allocation of land resources to protein crop production instead of for instance cereal production. There are different tradeoffs which would require further investigations including: 1) how does changing land use from e.g. cereals to legumes or rapeseed affect local environmental load, and 2) how does environmental load of local protein supply differ from that of imported crop protein when the effects of overseas transportation are taken into account. Environmental amenities are of primary importance from the policy viewpoint, because they can justify policies which promote local production of protein crops.

\section{Sustainable means to increase domestic protein supply in future? Unrealized potential for expansion of cultivation}

The role of legumes in farming systems has historically been important in sustaining plant production, but such production systems have faced biological, economic and/or environmental forces causing change in their use (Howieson et al. 2000). Pea and faba bean were grown by early farmers in Finland, with remains dated to 500 BC (Stoddard et al. 2009). During the last century their area under cultivation did not change substantially when compared with the total available arable land in Finland. Pea was grown at most on 16000 hectares, but since 1990 its cropping area stagnated at around 4000 hectares only, despite clear improvements in lodging resistance and thereby, production security (Hovinen 1988a). Today the most lodging resistant pea cultivars can be grown successfully as pure stands (Kontturi et al. 2011). However, intercropping may provide a means for more stable production (Kontturi et al. 2011). Therefore, intercropping has typically been more common in the northern regions of Finland with higher production risks compared with southern parts of the country where pure stands are predominant (Tike 2012). 


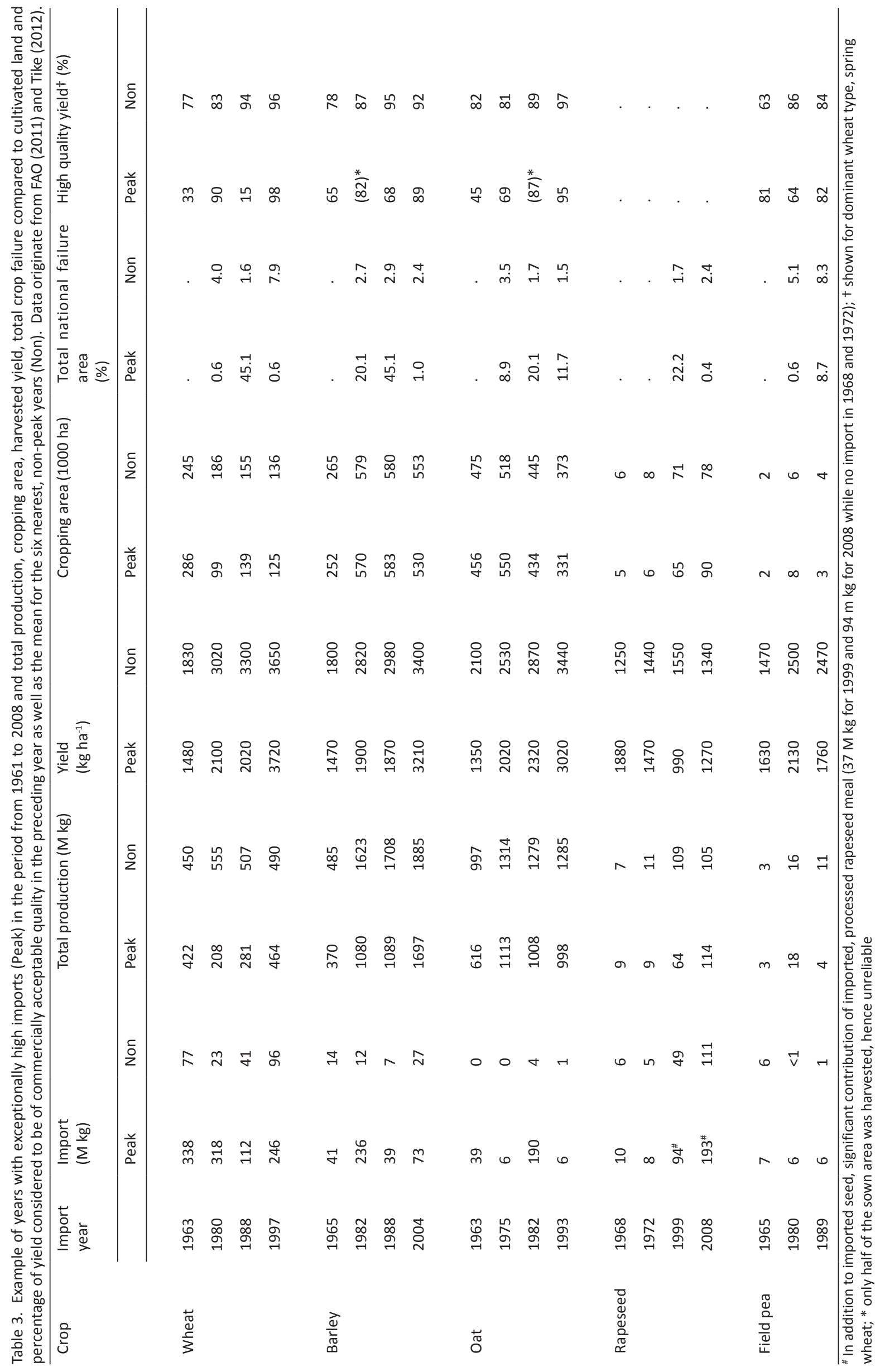


Landraces of faba bean were grown in marginal areas, but in 1969 plant breeding programs were initiated to develop cultivars adapted to Finnish conditions, to partly substitute for imported protein feeds (Hovinen 1988b). Two cultivars were released, but without any increase in cultivation area (Stoddard et al. 2009). Only during the very recent past has interest in growing faba bean increased and they have been grown a lot in pure stands. Rapeseed was introduced into cultivation as a novel crop in the mid $20^{\text {th }}$ century, but it only broke through since the $1970 \mathrm{~s}$ when unreliable winter cultivars were replaced by good spring types of superior quality. Early maturing blue lupin (Lupinus angustifolius L.) cultivars also have potential as a novel protein crop for northern agriculture (Anizewski 1988a, 1988b, Kurlovich et al. 2004). The crop needs to be further investigated as it is presently grown on a very limited scale (Stoddard et al. 2009).

When exploring the opportunities to increase production of protein crops in Finland, including rapeseed and leguminous species, a sufficiently long growing season is required to sustain quality and quantity. Differences between regions exist regarding early summer precipitation and formation of yield potential, as well as for likelihood of harmful, excess precipitation during late seed filling and harvest (Fig. 7). A more critical issue regarding expansion of protein crop production area is whether cumulated degree days for a region are sufficient to avoid recurrent uncertainties and crop failures.

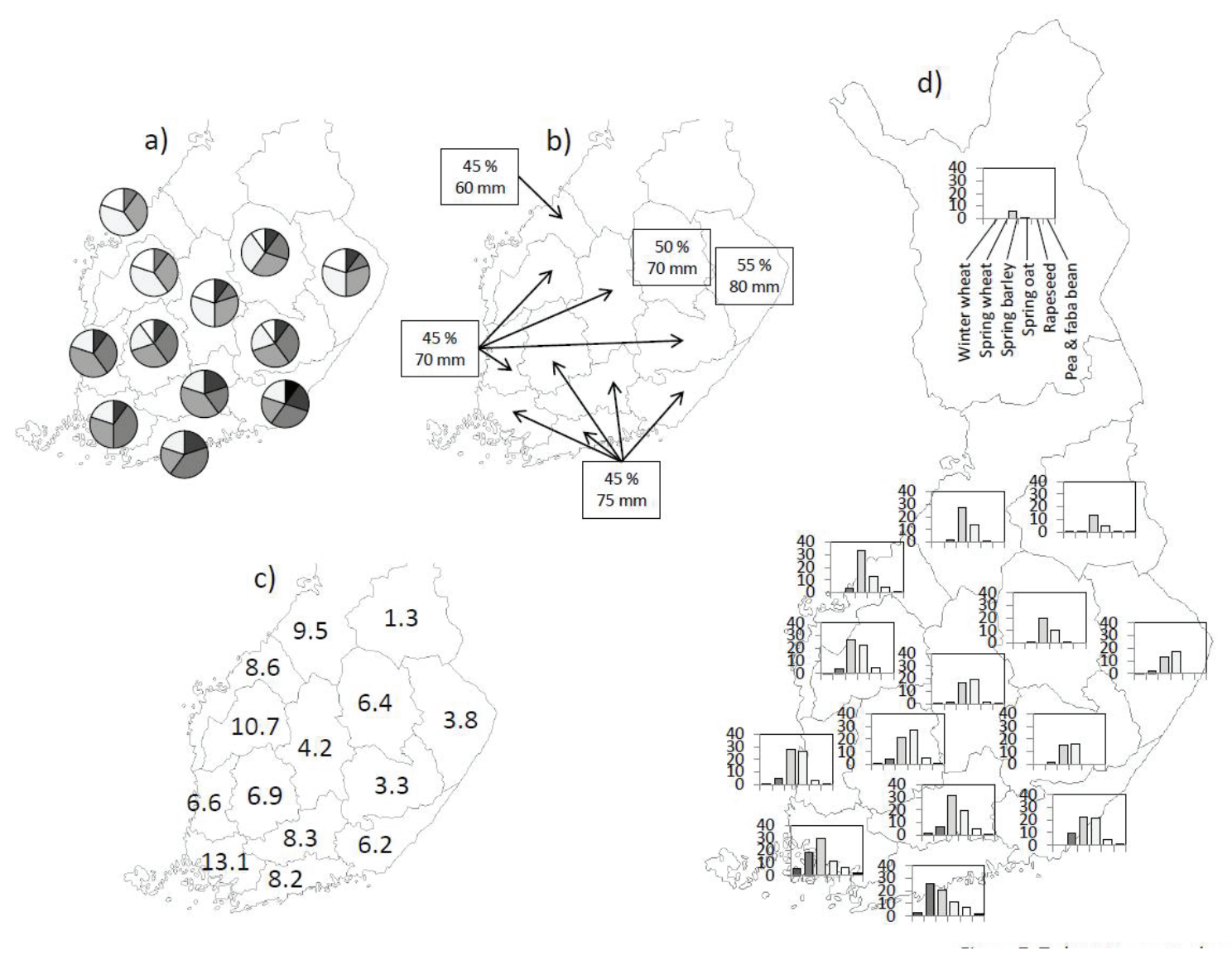

Fig. 7. Regional differences in Finland for a) probabilities of having growing seasons with $800,900,1000,1100,1200$, and $1300{ }^{\circ} \mathrm{Cd}$ within 10 year periods according to data from 1971-2000 provided by the Finnish Meteorological Institute (Peltonen-Sainio et al. 2009b), b) 30 year mean (1971-2000) for proportion of accumulated precipitation during the most critical phase of yield determination when compared to requirement for undisturbed growth and accumulated precipitation in August (mm) that is deleterious for harvest (Peltonen-Sainio et al. 2011d), c) contribution to total agricultural land as well as d) proportion of cultivated area for each crop to total arable land in a region in 2001-2010. Data from Tike (2012).

According to long-term climate datasets (Peltonen-Sainio et al. 2009b), of a total of 15 Finnish provinces, 12 contributed $>3 \%$ to national agricultural land and of these five had $\geq 80 \%$ and two $~ 70 \%$ of growing seasons with sufficient cumulated degree days, exceeding $1000^{\circ} \mathrm{Cd}$, from sowing to mid-September. Such a temperature sum is critical to enable cultivation of protein crops. The requirement is 890,960 and $990{ }^{\circ} \mathrm{Cd}$ for spring barley, oat and wheat, whilst it is 1010 and $1090^{\circ} \mathrm{Cd}$ for turnip rape and oilseed rape and $930-980$ and $1060{ }^{\circ} \mathrm{Cd}$ for pea and faba bean (Peltonen-Sainio et al. 2009a). 
When roughly estimating the theoretical maximum potential for increasing protein crop production area, it is important to consider that at most only $20 \%$ of the total agricultural land is available for protein crops. This is because they require that the maximum frequency for protein crops in a crop rotation is once in four to five years to reduce production risks and crop failures caused by diseases and insect pests (Donald and Porter 2009, Jensen et al. 2010, Stoddard et al. 2010). In the seven southern regions, with most potential, only $0.9-8.6 \%$ of arable land is currently devoted to protein crops. Hence, with a $20 \%$ theoretical maximum share for each protein crops (rapeseed and legumes) cropping area could be increased to five times the present area. Consequent increases in total protein production capacity, however, depends on how the cropping area is balanced between potential protein crops that differ in their protein yields, seed protein contents and composition (Hovinen 1988a, 1988b, Duranti and Gius 1997, Kontturi et al. 2011, Peltonen-Sainio et al. 2011a, 2011b) and whether faba bean cultivars that are free of harmful tannins, visine and convisine, which limit its use for monogastric animals (Crépol et al. 2010), will also be available for northern conditions. This preliminary estimate indicates the general potential for increases in protein crop production and encourages detailed estimates to be made for expansion potential. Such estimates need to take into consideration e.g., regional differences in balance between success and serious production risks for different protein crops, their soil requirements (field sizes, soil types, soil conditions) and their potential to substitute for imported soybean-based protein in animal feeds.

In 2008, Finland imported rapeseed (193000 t), rapeseed meal (94000 t) and soybean meal (174 000 t) (FAO 2011) and produced only $25 \%$ of the rapeseed based protein used for animal feed. Hence, it is evident that expansion of protein crop production can have effects on national feed supply and feed imports. However, when taking into account the limitations for expansion of protein crop production resulting from crop rotation requirements (compare monocultures that are typical and possible for cereal production at present) and northern growing conditions in general, one can conclude that the likelihood of significantly increasing Finland's contribution to total European production of protein crops through intensification remains small. To have any effect on a global scale appears impossible. Nevertheless, it is necessary to consider risks for yield instability and crop failures to avoid volatility in markets, inefficient resource use and the concomitant risk for leaching of excess nitrogen in the environment, especially as leaching risk is particularly high for rapeseed (Peltonen-Sainio and Jauhiainen 2010). On the other hand, methods that stabilize yields, such as use of fungicides, reduce the risk nitrogen leaching (Sieling and Kage 2006). Insufficient crop protection is presently reducing rapeseed resource use efficiency in Finland (Asko Hannukkala, personal communication $2^{\text {nd }}$ February 2011). Improvement of adaptive capacity of protein crops for current and future conditions means developing resilient cropping systems and risk avoidance mechanisms, including crop rotation with nitrogen efficiently captured by crops subsequent to rapeseed and nitrogen-fixing leguminous crops.

\section{Ecosystem services provided by protein crops}

Important drivers for future increases in protein crop production in Finland include the ecological services that protein crops provide. Services are direct or as in most cases indirect (Köpke and Nemecek 2010). A typical direct ecosystem service provided by leguminous crops is that they fix atmospheric nitrogen and when crop rotations are successfully managed, nitrogen that leguminous crops release for the following crop may markedly reduce the need for fossil fuel based nitrogen fertilizers that affect the carbon footprint of crop production (Stoddard et al. 2009, Jensen et al. 2010, Köpke and Nemecek 2010, Moran et al. 2011). Faba bean does not require nitrogen fertilizers (Jensen et al. 2010), and pea only "starter nitrogen" for early growth and plant stand establishment (McKenzie et al. 2001). Comprehensive analyses are needed and available for estimation of public goods provided by legumes such as potential for reducing nitrogen fertilizer use (Salvagiotti et al. 2008). It can be roughly estimated that in Finland, by expanding pea and faba bean production nitrogen fertilizer use could be reduced by 2.5 million $\mathrm{kg}$ per year in the case that residual nitrogen from leguminous crop is a reasonable estimate of only $\sim 30 \mathrm{~kg}$ ha-1 $^{-1}$ Rathke et al. 2005, López-Bellido et al. 2006, Stoddard et al. 2009, Jensen et al. 2010) and half of the potential area is devoted to leguminous crops (other half for rapeseed). Developing nitrogen management in agronomy not only through enhancing nitrogen use efficiency of crops and cropping systems, but also through supporting and utilizing nitrogen fixation and release from leguminous crops in rotations is an important means to meet the requirements for ecological intensification, energy savings and efficiency as well as reduction in greenhouse gas emissions in the future (Li et al. 2002, Rathke and Diepenbrock 2006, Salvagiotti et al. 2008, Köpke and Nemecek 2010, Doré et al. 2011).

Diversification of crop production and cropping systems is another multidimensional ecosystem service that protein crops provide (Köpke and Nemecek 2010). When historic land use data was assessed, Lautenbach et al. (2011) indicated that the ecosystem functioning has degraded in a certain area of East Germany over the last four decades and changes in land use configurations played an important role in this degradation. Such findings em- 
phasize the need for diversifying the cereal-dominating cropping systems also in the northern European growing conditions. As referred to above, one lesson that was learned from the last extensive crop failures at the end of $19^{\text {th }}$ century, was loosening the dependency on sole grain crop production that also depleted the soils of nutrients (Mukula 1981d). Today there is again an obvious need for crop diversification in Finnish crop rotations (Keskitalo et al. 2010). Protein crops with potential for Finnish growing conditions, rapeseed, pea and faba bean, have many advantages as break crops, such as ability to break disease cycles, encourage greater soil fertility and microbial activity and diversity in soils, exert beneficial effects on soil structure and provide residual nitrogen through leguminous crops (Howieson et al. 2000, Karpenstein-Machan and Stuelpnagel 2000, Smith et al. 2004, Shahbaz et al. 2006, Kirkegaard et al. 2008, Jensen et al. 2010, Köpke and Nemecek 2010). As break crops, rapeseed and legumes may offer a means to suppress weed growth, due to differential potential to compete with weeds (Zoschke and Quadranti 2002), which in turn may enable reduced herbicide doses (Blackshaw et al. 2006). This, however, requires that these crops exhibit a rapid early development, short vegetation period and/or dense canopies, which are presently sometimes challenges for rapeseed in Finland.

Spring sown cereals are often grown as monocultures in Finland, especially in the southwestern provinces, which have the highest potential yields per hectare due to having the longest growing seasons (Fig. 7a). In contrast, the northern regions of Finland have dairy production and large areas of grassland in rotations. Subsoil compaction is recognized to be a significant problem in Europe, including Finland, especially in the high potential southern regions (Alakukku 1999). The tap root of rapeseed cannot, however, penetrate into strongly compacted soil, but it can probably alleviate soil compaction if the soils enable roots to find their way down even after the first winding (Peltonen-Sainio et al. 2011e). Soil compaction and resultant rapeseed root penetration restrictions are more common in direct-drilled soils. This also means that until Finnish fields are too heavily compacted, diversified crop rotations are needed to prevent gradual soil deterioration. While rapeseed (Peltonen-Sainio et al. 2011e) may have difficulties in heavily compacted soils, faba bean has the capacity to push through extremely hard soils (Martti Yli-Kleemola, personal communication $2^{\text {nd }}$ February 2011). On the other hand, Muños-Romero et al. (2011) and Lopéz-Bellido et al. (2011) showed that no-tillage favored development of the faba bean root system and nitrogen economy more compared with conventional tillage in a Mediterranean Vertisol.

Another dimension of diversification of agroecosystems is crop-pollinator interplay. The ongoing declines in pollinator populations at local and global scale cause serious concerns (Biesmeijer et al. 2006). Flower-rich habitats of oilseed rape improve early colony growth of bumblebees (Bombus sp.), important generalist pollinators, though it does not increase the likelihood of colonies to produce sexual offsping (Westphal et al. 2009). Ecosystem services are mutual as services provided by a mass flowering crop for pollinators (Westphal et al. 2009) are rewarded by higher seed set (Benachour et al. 2007, Jauker and Wolters 2008). This together with other above mentioned ecosystem services often associate with increased productivity and system resilience (Köpke and Nemecek 2010). On the other hand, mass flowering oilseed rape may also distort plant-pollinator interactions as certain pollinators may benefit at the expense of other species (Diekötter et al. 2010).

The concept of ecological services is wide as it covers a number of commodities and services that the environment offers for human existence and well-being. In addition to above described services for development and management of sustainable agroecosystems, rapeseed provides also supply services such as raw-materials for different industrial applications: vegetable oil for food and biodiesel use as well as protein-rich rapeseed meal for livestock feed. Climate change has speed up development of alternative renewable energy sources for fossil fuels (Cassman and Liska 2007) and calls for means and solutions to balance between food supply and bioenergy production (Cassman 2007). Debate between needs for food security and climate change mitigation is not, however, as critical for rapeseed compared with many other field crops as the oil component of rapeseed yield needs alternative uses for processing others than food oil in order to be able to produce as a co-product the high-quality protein feed in European arable land.

\section{Climate change}

Climate change is important from the policy point of view. Firstly, climate change can justify policies supporting the production of protein crops under the northern conditions if these policies are able to mitigate greenhouse gas emissions - compared to the alternative that the same amount of crop protein would be produced elsewhere and imported to northern regions. However, it is not clear whether switching from imported to locally produced crop protein is environmentally viable in this sense. Secondly, climate change in the northern hemisphere will likely offer some new opportunities to expand protein crop production (Peltonen-Sainio et al. 2009a) if the growing season is prolonged as projected (Jylhä et al. 2010). Production security is, however, likely be uncertain in the 
future. Climate change induced alterations in occurrence of extreme events (Meehl and Tebaldi 2004, Schär et al. 2004, Planton et al. 2008) and climatic constraints (Trnka et al. 2011), as well as differences between crops, cropping systems and farm characteristics in their vulnerability, responsiveness and ability to cope with unfavorable conditions (Reidsma and Ewert 2008, Reidsma et al. 2010, Bindi and Olesen 2011, Peltonen-Sainio et al. 2011c, 2011d) per se determines the balance between success and failure of crops and cropping systems.

Crop failure risks related to incidence of pests and diseases will probably increase (Ghini et al. 2008, Evans et al. 2010, Cahkraborty and Newton 2011, Luck et al. 2011) also in the north (Hakala et al. 2011) because many insects and pathogens can complete more reproductive cycles in a warmer climate (Bale et al. 2002, Salinari et al. 2006). This may be especially critical for rapeseed and leguminous seed crops, for which there is currently need for crop protection on a larger scale than for cereals, but also because expansion of their cultivation is likely to increase the risks for disease and pest infestation (Huusela-Veistola and Jauhiainen 2006, Peltonen-Sainio et al. 2012). Therefore, when determining the future strategic goals for sustainable expansion of protein crop production, climate change impacts need to be taken into account.

Emphasis on production of biofuels has provided new opportunities for rapeseed production and utilization in Europe. Coarse grains are the primary raw material for ethanol production, whereas rapeseed oil is the primary raw-material for biodiesel processing (80 \%) in EU, the rest shared by palm oil and soybean oil (OECD-FAO 2011, see also http://www.agricommodityprices.com). Two thirds of the total rapeseed oil is used for biodiesel production. The increase in demand for rapeseed oil for biodiesel is, however, expected to slow down, while human consumption of oil likely continues to increase slowly and steadily.

Biofuel production has important implications in the world's protein feed market. Firstly, it increases the supply of protein-rich meals and grains which are obtained as by product of biofuel processing, such as rapeseed meal from oil processing. EU is the major user of rapeseed meal in animal feeds in the world. Capacity for further increases in rapeseed meal production exists, and it also offers a competitive alternative to GMO-free soybean meal imported from Brazil and Argentina. Secondly, oilseed prices are expected to rise in the world market in the current decade, thus maintaining economic incentives for their production. By contrast, and due to increasing biofuel production, soybean and rapeseed meal prices are expected to decrease in the world market, and thus strengthen economic incentives to increase their use in animal feeds (e.g. OECD-FAO 2011, Fapri 2011, USDA 2011, European Commission 2010). These policy and climate change-related global trends are important factors affecting demand, supply and price of crop-based protein.

\section{Economic feasibility of, and policies for expansion}

From the economic point of view, the key issues regarding the potential of rapeseed and grain legumes production are whether their cultivation is profitable compared with other field use alternatives and whether their utilization as feed is economically rational. This is due to the fact that animals are an important group using crop-based protein in Finland. Rapeseed is an important source of protein for ruminants whereas legumes fed to monogastric animals are considered having a considerable potential. Since the prices of local crop products are mainly determined in the global market, it is of primary importance that cultivation costs are low enough when compared with imported sources of protein. This is challenging, because in the northern conditions crop yields are typically lower than elsewhere (Peltonen-Sainio et al. 2009c).

An alternative to improve the profitability of protein crop production would be to ask for a higher price premium for the crop. However, this would reduce the demand for domestic protein crops when compared with imported high-protein sources, whose prices on the world market would remain unchanged (Juntti et al. 2005; Niemi et al. 2011). Hence, policies could promote local protein crop production by measures 1) which reduce the costs of cultivation per tonne of crop product and 2) increase subsidies to the crops' cultivation but not their market prices, e.g. through the supply of environmental amenities. Public policies can help to reduce costs of cultivation for instance through education and advisory services, research and development, risk management tools and other infrastructures. Measures to support output are not viable because subsidies coupled to yields can distort the market and thus are not favored by the World Trade Organization. Preferred alternative would probably be to promote the provision of public goods associated with protein crops, e.g by supporting versatile crop rotation, improved soil structure and reduced nitrogen fertilization. When determining the need for such policy measures, one must assess their possibilities to make the difference. 
Because economic return on land is critical for its allocation to protein-rich crops, we conducted a simulation analysis of gross margins and their volatility. The analysis was meant to evaluate how the average profitability of crops varies. Yield variation at the farm level can be more prominent than presented here. Firstly, gross margins for feed barley, rapeseed, field pea and faba bean cultivated in subsidy region B, which is in southern Finland, excluding the southernmost area, were calculated. The standard cost calculations for barley and rapeseed were based on model calculations by Tuottopehtoori (ProAgria 2012), an internet-based tool to compare the return on different crops and the various factors which impact their costs of production. The calculations for field pea and and faba bean were based on data obtained from Juntti et al. (2005) and MTT's expertise on their cultivation. The average yield and price levels were adjusted to meet the average yield (Tike 2012) and typical price (OSF 2012a,b) levels in Finland in 2011 (see Table 4).

Table 4. Simulated mean value (Value, detrended data) and coefficient of variation (CV, \%) of yield, price of yield, different cost and income lines and return on fixed assets (total revenues minus variable and labour cost).

\begin{tabular}{|c|c|c|c|c|c|c|c|c|}
\hline & \multicolumn{2}{|c|}{ Feed Barley } & \multicolumn{2}{|c|}{ Rapeseed } & \multicolumn{2}{|c|}{ Field pea } & \multicolumn{2}{|c|}{ Faba bean } \\
\hline & Value & $\mathrm{CV}$ & Value & $\mathrm{CV}$ & Value & $\mathrm{CV}$ & Value & $\mathrm{CV}$ \\
\hline Yield, kg ha-1\# & 3545 & 5 & 1284 & 13 & 2415 & 7 & 3000 & 7 \\
\hline Yield price, $€ \mathrm{t}^{-1^{+}}$ & 170 & 15 & 420 & 12 & 200 & 12 & 230 & 12 \\
\hline \multicolumn{9}{|l|}{ Revenues } \\
\hline Market revenues, $€$ ha $^{-1}$ & 603 & 16 & 538 & 16 & 484 & 14 & 691 & 14 \\
\hline Subsidies, $€$ ha $^{-1 *}$ & 590 & 0 & 594 & 0 & 594 & 0 & 594 & 0 \\
\hline Total revenues, $€$ ha-1 $^{-1}$ & 1193 & 8 & 1132 & 8 & 1078 & 6 & 1285 & 7 \\
\hline \multicolumn{9}{|l|}{ Variable costs $€$ ha $^{-1+t}$} \\
\hline Seed & 108 & 12 & 46 & 5 & 135 & 5 & 135 & 5 \\
\hline Fertilizers and limestone & 147 & 14 & 192 & 14 & 80 & 14 & 84 & 14 \\
\hline Herbicides and pesticides & 52 & 7 & 109 & 7 & 69 & 7 & 69 & 7 \\
\hline Energy (machinery, drying) & 137 & 8 & 86 & 8 & 78 & 8 & 78 & 8 \\
\hline Transport of yield to market & 68 & 6 & 26 & 13 & 48 & 7 & 60 & 7 \\
\hline Costs of operating capital & 17 & 6 & 16 & 6 & 15 & 4 & 15 & 4 \\
\hline Variable costs, total $€$ ha $^{-1}$ & 529 & 8 & 474 & 8 & 425 & 6 & 441 & 6 \\
\hline Cost of labour** & 179 & 0 & 179 & 0 & 179 & 0 & 179 & 0 \\
\hline Return on fixed assets & 485 & 14 & 479 & 13 & 474 & 12 & 665 & 12 \\
\hline
\end{tabular}

\# Detrended values for year 2011 based on data by Tike (2012). Yield of faba bean based on expert data.

† Detrended values for year 2011 based on data by OSF (2012a), ProAgria (2012) and a compilation of buyers' websites. Because the price volatility of field pea and faba bean could not be estimated, their volatility has been assumed similar to that of rapeseed.

* Subsidy payments per hectare for eligible for a crop farm in subsidy region B in 2011.

$+\dagger$ Input quantities are assumed fixed whereas input prices are volatile. Quantities and average prices were estimated based on ProAgria (2001), Juntti et al. (2005), Niemi et al (2011) and authors' own calculations. Price and cost volatility was simulated using detrended estimates based on data by Tike (2012) and OSF (2012b)

** Based on ProAgria (2001). 
Secondly, the effects of systemic risks on cash flow were simulated using Monte Carlo simulation and statistical price (OSF 2012a,b) and yield data (Tike 2012) (annual data) for year 2000 to 2011 as follows. Time trends of yields and price indices were eliminated from the data by using a least squares method (a price index or a yield explained by an intercept and a time trend). Thereafter, estimated prices and yields for 2011 were used as the baseline. Residuals of the model were used to develop a variance-covariance matrix, which was further used when simulating the distributions of yield and price indices. Because there were no annual price data available for field pea or faba bean, their price volatility was assumed to be similar to that of rapeseed. It should be noted that simulated results in Table 4 characterize systemic year-to-year variations in revenues, costs and returns on cultivation of specific crops on average. As the results are based on simulated data, annual variation in degree days, precipitation etc. is implicitly included in the results. However, local variation may be larger than represented in Table 4, and at the farm level variations are likely to be larger than presented here.

Detrended results in Table 4 suggest that, based on statistical average data only, annual rapeseed and field bean price volatility would be smaller than price volatility of barley. Large price volatility of feed barley is mainly due to grain price peaks experienced in 2007 to 2011. These few individual years also led to larger total incomes and returns on fixed assets for feed barley than for rapeseed, faba bean or field pea. Assuming that the national average yield would be obtained, there were no substantial differences in the average returns on fixed assets from feed barley, rapeseed or field pea. However, faba bean resulted in a higher return than the three other crops. These results suggest that it is economically realistic to expand the cultivation of faba bean. Rather equal margins for three other crops suggest that they all can be quite equally competitive choices in specific situations. However, it should be noticed that the average yield for barley is rather low, and that a lower subsidy per hectare is paid for barley than for the three other crops. At many farms it is possible to reach considerably higher average cereal yield, but it is not known whether they would be able to obtain much higher rapeseed or legume yields.

Coefficients of variation in Table 4 also suggest that economic return on the cultivation of cereals may be more volatile than those of rapeseed, field pea or faba bean. This is an interesting result arising from the turbulence of cereal markets after harvests in autumn 2007. The results illustrate that besides yield variability, economic risks are determined also by other important factors which may not show strong negative correlation with yield in a small market such as Finland. Although price volatilities of field pea and faba bean were hypothetical (see Table 4), statistics provide some evidence that their coefficients of variation would be smaller than that of cereal prices.

Rapeseed production is challenged by high fertilizer costs (Niemi et al. 2011) and further by the crop's inefficient nitrogen use (Peltonen-Sainio and Jauhiainen 2010). Access to low-priced nitrogen fertilizer would therefore promote rapeseed production. A previous study (Niemi 2003) analyzing land allocation in crop farms panel data found weak evidence that rapeseed areas would increase quite elastically with area-based subsidies and the price of rapeseed. More significant factors contributing to the rapeseed area at the farm were low subsidies paid for cereal area and large size of a farm. This suggests that policies aiming at increased cultivation of rapeseed should improve return on rapeseed area when compared with cereal area. Furhter, Kondouri et al. (2009) found that owners of small Finnish crop farms were more risk averse than those of larger ones. Hence, small farms would benefit the most from policy measures which reduce risks associated with the cultivation of these crops. Risk management policies could therefore provide extra coverage against yield risk faced by cultivation of rapeseed, pea and faba bean.

The evident bottleneck for pea cultivation in Finland is the high price of certified seed. In some cases, certified pea seed can cost even more than is the value of harvested yield (Juntti et al. 2005). Besides high-quality seed production, public policies could promote pea and faba bean production by investments in plant breeding with the goal of developing high-yielding and robust varieties, as is presently the case in Finland. Expansion of cultivation of the pea crop would likely markedly increase volumes of certified seeds in the market and reduce the unit price.

With reasonable average yields rapeseed, pea and faba bean are able to provide higher profit margin than feed barley, but the uncertainty caused by abiotic and biotic constraints should not exceed that in other crops to attract the risk-averse farmers (Niemi et al. 2011). As ecosystem services of protein crops in a cereal-dominated cropping system may be significant, as described above, but often indirect (compare with reduction in nitrogen fertilizer use) and hard to value, we need more comprehensive assessments at cropping system level about the benefits provided by rapeseed and legumes. The risks could be addressed also at the farm level because there they may have a higher impact. Improvements in protein supply call for comprehensive solutions through the production chain but especially on the farms including increasing collaboration between farms. Increased collaboration could help to gain economies of scale in arable farming, and thus reduce production costs per unit and the role of risk on crop choices (Niemi et al. 2011). Such collaboration between some organic livestock and crop production farms 
already exists in Finland. Through agreed collaboration, abundantly produced manure is used to fertilize the fields of the organic crop production farms. In return, protein crops that diversify crop rotations in crop production farms are used as feed protein by collaborating livestock farm. Policies could support such developments by facilitating crop and livestock farmers to meet and by supporting environmental amenities associated with such collaboration.

Today protein crops in the EU are entitled to roughly similar subsidies as cereals. In the future, CAP has the strategic aim to preserve the food production potential on a sustainable basis throughout the EU, thereby, to guarantee long-term food security and to contribute to a growing world food demand, which is expected to increase by $70 \%$ by 2050. Although the possibilities of national governments in Europe to boost protein production are limited, forthcoming CAP reform may provide opportunities to strengthen the cultivation of protein crops. The EU commission has proposed CAP measures to get "greener", meaning that more focus is given to alleviating environmental risks and damages caused by agriculture [European Commission, COM (2010) 672 dated $18^{\text {th }}$ November 2010]. Although CAP beyond 2013 is still open, it may benefit protein crop production. For example, the EU commission [European Commission, COM (2011) 625 dated 12 ${ }^{\text {th }}$ October 2011] is proposing farmers to have at least three different crop species in cultivation, each contributing at least $5 \%$ of land acerage and none exceeding $70 \%$. As under the northern European conditions cereal monocultures dominate in field crop agriculture, and the number of crops for diversification, is limited, cultivation of rapeseed and grain legumes might be particularly enhanced along with such a CAP reform. Another obvious option is to cultivate at least three cereal species. Hence, this may require that policies advance protein crop markets, facilitate collaboration between farms, and particularly provide farmers with economic incentives making rapeseed, pea and faba bean cultivation economically more favorable than that of cereals.

\section{Conclusion}

In conclusion, this descriptive analysis of the current status of protein crop production in Finland indicates that the northern margins of agricultural production cannot aspire to self-sufficiency in crop based feed protein production. However, current production capacities indicate a striking underutilization of protein crops, further provision of key ecosystem services by their cultivation and thirdly the protein-rich seed yield to be used for animal feed to a greater extent than presently. We conclude that protein crop production could be sustainably increased by doubling their present cropping areas in the northernmost European regions. While soybean is globally the most important protein crop, rapeseed and legumes can be Nordic options to meet the demand for crop protein. The analysis suggests that seed protein content, amino acid composition, existence of anti-nutritional factors, protein yield potential per hectare, capacity to substitute for soya protein in animal feed, especially for monogastric animals, production risk and economic incentives associated with the cultivation and feed use of protein crops production, environmental amenities as a justification of policy are essential elements to be considered when aiming at the expansion of protein crop production. The key questions to explore in more detail are e.g.: what are the sustainable future production volumes to aspire at, how to organize cultivation of potential protein crops on a regional basis in order to cope with the risks while utilizing increased ecosystem services that protein crops provide? From the socio-economic viewpoint it is important that policies secure environmental sustainability, keep risk under control and secure low production costs, which facilitate farmers to choose protein crops instead of cereals in cultivation, and domestic protein crops instead of imported protein grains in feed use. Given small differences in gross margins of cultivation, it is possible for policies and markets to advance the production of rapeseed and legumes.

\section{Acknowledgements}

This paper is dedicated to the dear brother of Pirjo Peltonen-Sainio, Dr. Agric. Jari Peltonen, who suddenly passed away at the age of 49 years. The work was financed by the Finnish Ministry of Agriculture and Forestry and MTT Agrifood Research Finland, and it was part of a project entitled Strengthening domestic protein self-sufficiency under the pressure of global changes (OMAVARA) and Sustainable intensification of cropping systems (SusIntent).

\section{References}

Alakukku, L. 1999. Subsoil compaction due to wheel traffic. Agricultural and Food Science in Finland 8: 333-351.

Aniszewski, T. 1988a. Initial development of three blue lupin (Lupinus angustifolius L.) varieties in northern Finland. Annales Agriculturae Fenniae 27: 141-151. 
Aniszewski, T. 1988b. Environment, phenological development and dry matter formation of the blue lupin (Lupinus angustifolius L.) varieties in northern Finland. Acta Agriculturae Scandinavica 38: 303-316.

Bale, J.S., Masters, G.J., Hodkinson, I.D., Awmack, C., Bezemer, T.M., Brown, V.K., Butterfield, J., Buse, A., Coulson, J.C., Farrar, J., Good, J.E.G., Harrington, R., Hartley, S., Jones, T.H., Lindroth, R.L. Press, M.C., Symrnioudis, I., Watt, A.D. \& Whittaker, J.B. 2002. Herbivory in global climate change research: direct effects of rising temperature on insect herbivores. Global Change Biology 8: 1-16.

Benachour, K., Louadi, K. \& Terzo, M. 2007. Role of wild and honey bees (Hymenoptera: Apoidea) in pollination of Vicia faba L. var. major (Fabaceae) in Constantine area (Algeria). Annales de la Societe Entomologique de France 43: 213-219.

Biesmeijer, J.C., Roberts, S.P.M., Reemer, M., Ohlemuller, R., Edwards, M., Peeters, T., Schaffers, A.P., Potts, S.G., Kleukers, R., Thomas, C.D., Settele, J. \& Kunin, W.E. 2006. Parallel declines in pollinators and insect-pollinated plants in Britain and the Netherlands. Science 313: 351-354.

Bindi, M. \& Olesen, J.E. 2011. The response of agriculture in Europe to climate change. Regional Environmental Change 11 (suppl. 1): 151-158.

Blackshaw, R.E., O’Donovan, J.T., Harker, K.N., Clayton, G.W. \& Stougaard, R.N. 2006. Reduced herbicide doses in field crops: A review. Weed Biology and Management 6: 10-17.

Briffa, K.R., Jones, P.D., Schweingruber, F.H. \& Osborn, T.J. 1998. Influence of volcanic eruptions on Northern Hemisphere summer temperature over the past 600 years. Nature 393: 450-455.

Cassman, K.G. 2007. Climate change, biofuels, and global food security. Environmental Research Letters 2: 1-3.

Cassman, K.G. \& Liska, A.J. 2007. Food and fuel for all: realistic or foolish. Biofuels, Bioproducts \& Biorefining 1: 18-23.

Chakraborty, S. \& Newton, A.C. 2011. Climate change, plant diseases and food security: an overview. Plant Pathology 60: 2-14.

Cousin, R. 1997. Peas (Pisum sativum L.). Field Crops Research 53: 111-130.

Crépol, K., Marget, P., Peyronnet, C., Carrouée, B., Arese, P. \& Duc, G. 2010. Nutritional value of faba bean (Vicia faba L.) seeds for feed and food. Field Crops Research 115: 329-339.

de Silva, S.L. \& Zielinski, G.A. 1998. Global influence of the AD 1600 eruption of Huaynaputina, Peru. Nature 393: 455-458.

Diekötter, T., Kadoya, T., Peter, F., Wolters, V. \& Jauker, F. 2010. Oilseed rape crops distort plant-pollinator interactions. Journal of Applied Ecology 47: 209-214.

Donald, C. \& Porter, I. 2009. Integrated control of clubroot. Journal of Plant Growth Regulation 28: 289-303.

Doré, T., Makowski, D., Malézieuxm E., Munier-Jolain, N., Tchamitchian, M. \& Tittonell, P. 2011. Facing up to the paradigm of ecological intensification in agronomy: Revisiting methods, concepts and knowledge. European Journal of Agronomy 34: 197-210.

Duranti, M. \& Gius, C. 1997. Legume seeds: protein content and nutritional value. Field Crops Research 53: 31-45.

Engqvist, L.G., \& Ahvenniemi, P. 1997. Interactions between common root rot (Aphanomyces euteiches) and peas (Pisum sativum) in Finland. Acta Agriculturae Scandinavica, Section B., Soil and Plant Science 47: 242-247.

European Commission 2010. Prospects for agricultural markets and income in the EU 2010 - 2020.. European Commission, Directorate-General for Agriculture and Rural Development, Brussels. 78 p. Cited 30 May 2012. Available at http://ec.europa.eu/ agriculture/publi/caprep/prospects2010

FAO 2011. FAO Statistics Database, FAOSTAT-Agriculture. Cited 12 April 2012. Available online at http://faostat.fao.org

Fapri 2011. FAPRI-ISU 2011 world agricultural outlook database. Cited 30 May 2012. Available online at http://www.fapri.iastate. edu/ tools/outlook.aspx

Evans, N., Butterworth, M.H., Baierl, A., Semenov, M.A., West, J.S., Barnes, A., Moran, D. \& Fitt, B.D.L. 2010. The impact of climate change on disease constraints on production of oilseed rape. Food Security 2: 143-156.

Fullbrook, D. 2010. Food as security. Food Security 2: 5-20.

Ghini, R., Hamada, E. \& Bettiol, W. 2008. Climate change and plant diseases. Scientia Agricola 65: 98-107.

Hakala, K., Hannukkala, A., Huusela-Veistola, E., Jalli, M. \& Peltonen-Sainio, P. 2011. Pests and diseases in a changing climate: a major challenge for Finnish crop production. Agricultural and Food Science 20: 3-14.

Hannukkala, A. 1988. Diseases of rapeseed in Finland. GCIRC Bulletin 4: 23-25.

Hartman, G.L., West, E.D. \& Herman, T.K. 2011. Crop that feed the World 2. Soybean - worldwide production, use, and constraints caused by pathogens and pests. Food Security 3: 5-17.

Helama, S., Lindholm, M., Meriläinen, J., Timonen, M. \& Eronen, M. 2005. Multicentennial ring-width chronologies of Scots pine along north-south gradient across Finland. Tree-Ring Research 61: 21-32.

Holopainen, J. \& Helama, S. 2009. Little Ice Age farming in Finland: Preindustrial agriculture on the edge of the Grim Reaper's Scythe. Human Ecology 37: 213-225.

Hovinen, S. 1988a. Breeding of a protein pea ideotype for Finnish conditions. Journal of Agricultural Science in Finland 60: 1-72. Hovinen, S. 1988b. Breeding of field bean (Vicia faba L.) with early maturity. Journal of Agricultural Science in Finland 60: 261-267.

Howieson, J.G., O'Hara, G.W. \& Carr, S.J. 2000. Changing roles for legumes in Mediterranean agriculture: developments from an Australian perspective. Field Crops Research 65: 107-122.

Huusela-Veistola, E. \& Jauhainen, L. 2006. Expansion of pea cropping increases the risk of pea moth (Cydia nigricana; Lep., Tortricidae) infestation. Journal of Applied Entomology 130: 142-149.

Jauker, R. \& Wolters, V. 2008. Hover flies are efficient pollinators of oilseed rape. Oecologia 156: 819-823. 
Jensen, E.S., Peoples, M.B. \& Hauggaard-Nielsen, H. 2010. Faba bean in cropping systems. Field Crops Research 115: $203-216$.

Jestoi, M. N., Paavanen-Huhtala, S., Parikka, P. \& Yli-Mattila, T. 2008. In vitro and in vivo mycotoxin production of Fusarium species isolated from Finnish grains. Archives of Phytopathology and Plant Protection 41: 545-558.

Juntti, L., Pihamaa, P. \& Heikkilä, A.-M. 2005. Domestic protein from pea - are there economic preconditions for increasing cultivation? MTT:n selvityksiä 93. 34 p. (English abstract).

Jylhä, K., Tuomenvirta, H., Ruosteenoja, K., Niemi-Hugaerts, H., Keisu, K. \& Karhu, J.A. 2010. Observed and projected future shifts of climatic zones in Europe, and their use to visualize climate change information. Weather, Climate, and Society 2: 148-167.

Karpenstein-Machan, M. \& Stuelpnagel, R. 2000. Biomass and nitrogen fixation of legumes monocropped and intercropped with rye and rotation effects on subsequent maize crop. Plant and Soil 218: 215-232.

Keskitalo, M., Jauhiainen, L. \& Peltonen, S. 2010. Pellon käytön muutokset 1800-luvulta nykypäivään. Onko viljelykierto unohtunut? In: Hopponen, A. (ed.). Suomen Maataloustieteellisen Seuran Tiedote 26: 1 p. Suomen maataloustieteellinen Seura, Helsinki. (in Finnish).

Kirkegaard, J., Christen, O., Krupinsky, J. \& Layzell, D. 2008. Break crop benefits in temperate wheat production. Field Crops Research 107: 185-195.

Koundouri, P., Laukkanen, M., Myyrä, S. \& Nauges, C. 2009. The effects of EU agricultural policy changes on farmers' risk attitudes. European Review of Agricultural Economics 36: 53-77.

Kontturi, M., Laine, A., Niskanen, M., Hurme, T., Hyövelä, M. \& Peltonen-Sainio, P. 2011. Pea-oat intercrops to sustain lodging resistance and yield formation in northern European conditions. Acta Agriculturae Scandinavica, B Soil and Plant Science 61: 612-621. Köpke, U. \& Nemecek, T. 2010. Ecological services of faba bean. Field Crops Research 115: 217-233.

Kurlovich, B. S., Hovinen, S., Hyovela, M., Heinanen, J. \& Kulakov, N. 2004. Possibility of selection and cultivation of narrow-leafed lupin in Finland. In: Wild and cultivated lupins from the Tropics to the Poles. Proceedings of the 10th International Lupin Conference, Laugarvatn, Iceland. p. 56-58.

Lautenbach, S., Kugel, C., Lausch, A. \& Seppelt, R. 2011. Analysis of historic changes in regional ecosystem service provisioning using land use data. Ecological indicators 11: 676-687.

Li, F.-R., Gao, C.-Y., Zhao, H.-L. \& Li, X.-Y. 2002. Soil conservation effectiveness and energy efficiency of alternative rotations and continuous wheat cropping in the Loess Plateau of northwest China. Agriculture, Ecosystems and Environment 91: 101-111.

Lindholm, M. \& Eronen, M. 2000. A reconstruction of mid-summer temperatures from ring-widths of Scots pine since AD 50 in Northern Fennoscandia. Geografiska Annaler, Series A, Physical Geography 82: 527-535.

López-Bellido, L., López-Bellido, R.J., Redondo, R. \& Benítez, J. 2006. Faba bean nitrogen fixation in a wheat-based rotation under rainfed Mediterranean conditions: effect of tillage system. Field Crops Research 98: 253-260.

López-Bellido, R.J., López-Bellido, L., Benítez-Vega, J., Muñoz-Romero, V., López-Bellido,F.J. \& Redondo, R. 2011. Chickpea and faba bean nitrogen fixation in a Mediterranean rainfed Vertisol: Effect of the tillage system. European Journal of Agronomy 34: 222-230.

Luck, J., Spackman, M., Freeman, A., Trebicki, P., Griffiths, W., Finlay, K. \& Chakraborty, S. 2011. Climate change and diseases of food crops. Plant Pathology 60: 113-121.

Mann, M.E. 2002. Little Ice Age. In: MacCracken M.C. \& Perry J.S. (eds.). Encyclopedia of Global Environmental Change, vol. 1, The Earth System: Physical and Chemical Dimensions of Global Environmental Change. Chichester, United Kingdom: John Wiley \& Sons, Ltd. p. 504-509.

Mann, M.E. \& Bradley, R.S. 1999. Northern Hemisphere temperatures during the past millennium: Inferences, uncertainties, and limitations. Geophysical Research Letters 26: 759-762.

Mann, M.E., Bradley, R.S. \& Hughes, M.K. 1998. Global-scale temperature patterns and climate forcing over the past six centuries. Nature 392: 779-787.

Masuda, T. \& Goldsmith, P.D. 2009. World soybean production: Area harvested, yield, and long-term projections. International Food and Agribusiness Management Review 12: 143-162.

McKenzie, R.H., Middleton, A.B., Solberg, E.D., DeMulder, J., Flore, N., Clayton, G. W. \& Bremer, E. 2001. Response of pea to rhizobia inoculation and starter nitrogen in Alberta. Canadian Journal of Plant Science 81: 637-643.

Meehl, G.A. \& Tebaldi, C. 2004. More intense, more frequent, and longer lasting heat waves in the $21^{\text {st }}$ century. Science 305: 994-997.

Moran, D., MacLeod, M., Wall, E., Eory, V., McVittie, A., Barnes, A., Rees, R.M., Topp, C.F.E., Pajot, G., Matthews, R., Smith, P. \& Moxey, A. 2011. Developing carbon budgets for UK agriculture, land-use, land-use change and forestry out to 2022. Climatic Change 105: 529-553.

Moriondo, M., Bindi, M., Kundzewicz, Z.W., Szwed, M., Chorynski, A., Matczak, P., Radziejewski, M., McEvoy, D. \& Wreford, A. 2010. Impact and adaptation opportunities for European agriculture in response to climatic change and variability. Mitigation and Adaptation Strategies to Global Change 15: 657-679.

Mukula, J. 1981a. Suomen historian suuret katovuodet. Forssan Lehti $31^{\text {st }}$ October 1981. p. 6-7. (in Finnish).

Mukula, J. 1981b. Suomen historian suuret katovuodet. Satovahinkojen syyt ja seuraukset $1600-$ luvulla. Forssan Lehti $8^{\text {th }}$ November 1981. p. 8-9. (in Finnish).

Mukula, J. 1981c. Suomen historian suuret katovuodet. Suuret nälkävuodet 1867-1868. Forssan Lehti $15^{\text {th }}$ November 1981. p. 9-10. (in Finnish).

Mukula, J. 1981d. Suomen historian suuret katovuodet. Nälkävuosien tilinpäätös. Forssan Lehti $22^{\text {nd }}$ November 1981. p. 7-8. (in Finnish). 
Mukula, J. \& Rantanen, O. 1987. Climatic risks to the yield and quality of field crops in Finland. I. Basic facts about Finnish field crops production. Annals of Agriculturae Fennica 26: 1-18.

Mukula, J. \& Rantanen, O. 1989a. Climatic risks to the yield and quality of field crops in Finland. III. Winter rye 1969-1986. Annales Agriculturae Fenniae 28: 3-11.

Mukula, J. \& Rantanen, O. 1989b. Climatic risks to the yield and quality of field crops in Finland. IV. Winter wheat 1969-1986. Annales Agriculturae Fenniae 28: 13-19.

Mukula, J. \& Rantanen, O. 1989c. Climatic risks to the yield and quality of field crops in Finland. V. Spring wheat 1969-1986. Annales Agriculturae Fenniae 28: 21-28.

Mukula, J. \& Rantanen, O. 1989d. Climatic risks to the yield and quality of field crops in Finland. VI. Barley 1969-1986. Annales Agriculturae Fenniae 28: 29-36.

Mukula, J. \& Rantanen, O. 1989e. Climatic risks to the yield and quality of field crops in Finland. VII. Oats 1969-1986. Annales Agriculturae Fenniae 28: 37-43.

Muños-Romero, V., López-Bellido, L. \& López-Bellido, R.J. 2011. Faba bean root growth in a Vertisol: Tillage effects. Field Crops Research 120: 338-344.

Niemi, J.K. 2003. Land use response to agricultural policy and economic incentives on Finnish grain farms. In: Niemeläinen, $\mathrm{O}$. \& Topi-Hulmi, M. (eds.). Proceedings of the NJF's 22nd Congress on "Nordic Agriculture in Global perspective". Jokioinen MTT \& NJF. p. 164.

Niemi, J., Sipiläinen, T. \& Karhula, T. 2011. Protein self-sufficiency - feasible or not? In: Jyrki Niemi \& Jaana Ahlstedt (eds.). Finnish Agriculture and Rural Industries 2011. Maa- ja elintarviketalouden tutkimuskeskus, Agrifood Research Finland, Economic Research Publications 111: 30-31.

OECD-FAO 2011. OECD-FAO Agricultural Outlook 2011-2020. OECD, Paris. Cited 30 May 2012. Available online at http://www. agri-outlook.org

Official Statistics of Finland (OSF) 2012a. Producer Prices of Agricultural Products.

Information Centre of the Ministry of Agriculture and Forestry, Tike, Helsinki. [referred: 30.5.2012]. Available online at http:// www.tilastokeskus.fi/til/matutu/index_en.html.

Official Statistics of Finland (OSF) 2012b. Index of purchase prices of the means of agricultural production. Statistics Finland, Helsinki. Cited 30 April 2012]. Available online at http://www.tilastokeskus.fi/til/ttohi/index_en.html.

Olesen, J.E., Trnka, M., Kersebaum, K.C., Skjelvåg, A.O., Seguin, B., Peltonen-Sainio, P., Rossi, F., Kozyra, J. \& Micale, F. 2011. Impacts and adaptation of European crop production systems to climate change. European Journal of Agronomy 34: 96-112.

Peltonen-Sainio, P. 2012. Crop Production in a Northern Climate. In: Working papers of FAO/OECD Workshop Building resilience for adaptation to climate change in the agriculture sector on 23-24 April 2012, Chapter 4, Supporting thematic studies. 34 p. [referred: 15.5.2012]. Available online at http://www.oecd.org/dataoecd/43/47/50062683.pdf

Peltonen-Sainio, P., Hakala, K. \& Jauhiainen, L. 2011c. Climate induced overwintering challenges for wheat and rye in northern agriculture. Acta Agriculturae Scandinavica, B Soil and Plant Science 61: 75-83.

Peltonen-Sainio, P., Hannukkala, A., Huusela-Veistola, E., Voutila, L., Valaja, J., Niemi, J., Jauhiainen, L. \& Hakala, K. 2012. Potential and realities of enhancing rapeseed- and grain legume-based protein production in a northern climate. Journal of Agricultural Science in Cambridge. 19 p. Available online at http://journals.cambridge.org/action/displayAbstract?fromPage=online\&aid=8542041

Peltonen-Sainio, P. \& Jauhiainen, L. 2008. Association of growth dynamics, yield components and seed quality in long-term trials covering rapeseed cultivation history at high latitudes. Field Crops Research 108: 101-108.

Peltonen-Sainio, P. \& Jauhiainen, L. 2010. Cultivar improvement and environmental variability in yield removed nitrogen of spring cereals and rapeseed in northern growing conditions according to a long-term dataset. Agricultural and Food Science 19: 341-353.

Peltonen-Sainio, P., Jauhiainen, L. \& Hakala, K. 2009e. Are there indications of climate change induced increases in variability of major field crops in the northernmost European conditions? Agricultural and Food Science 18: 206-226.

Peltonen-Sainio, P., Jauhiainen, L. \& Hakala, K. 2011d. Crop responses to temperature and precipitation according to long-term multi-location trials at high-latitude conditions. Journal of Agricultural Science 149: 49-62.

Peltonen-Sainio, P., Jauhiainen, L., Hakala, K. \& Ojanen, H. 2009a. Climate change and prolongation of growing season: changes in regional potential for field crop production in Finland. Agricultural and Food Science 18: 171-190.

Peltonen-Sainio, P., Jauhiainen, L. \& Hannukkala, A. 2007b. Declining rapeseed yields in Finland: how, why and what next? Journal of Agricultural Science 145: 587-598.

Peltonen-Sainio, P., Jauhiainen, L., Hyövelä, M. \& Nissilä, E. 2011a. Trade-off between oil and protein in rapeseed at high latitudes: Means to consolidate protein crop status? Field Crops Research 121: 248-255.

Peltonen-Sainio, P., Jauhiainen, L., Laitinen, P., Salopelto, J., Saastamoinen, M. \& Hannukkala, A. 2011e. Identifying difficulties in rapeseed root penetration in farmers' fields in northern European conditions. Soil Use and Management 27: 229-237.

Peltonen-Sainio, P., Jauhiainen, L. \& Nissilä, E. 2011b. Improving cereal protein yields for high latitude conditions. European Journal of Agronomy 39: 1-8.

Peltonen-Sainio, P., Jauhiainen, L., Rajala, A. \& Muurinen, S. 2009d. Tiller traits of spring cereals in tiller-depressing long day conditions. Field Crops Research 113: 82-89.

Peltonen-Sainio, P., Jauhiainen, L., Trnka, M., Olesen, J.E., Calanca, P.L., Eckersten, H., Eitzinger, J., Gobin, A., Kersebaum, C., Kozyra, J., Kumar, S., Marta, A.D., Micale, F., Schaap, B., Seguin, B., Skjelvåg, A.O. \& Orlandini, S. 2010. Coincidence of variation in yield and climate in Europe. Agriculture, Ecosystems and Environment 139: 483-489. 
Peltonen-Sainio, P., Jauhiainen, L. \& Venäläinen, A. 2009b. Comparing regional risks in producing turnip rape and oilseed rape Today in light of long-term datasets. Acta Agriculturae Scandinavica, B Soil and Plant Science 59: 118-128.

Peltonen-Sainio, P., Kangas, A., Salo, Y. \& Jauhiainen, L. 2007a. Grain number dominates grain weight in cereal yield determination: evidence basing on 30 years' multi-location trials. Field Crops Research 100: 179-188.

Peltonen-Sainio, P., Rajala, A., Känkänen, H. \& Hakala, K. 2009c. Improving farming systems in northern European conditions. In: Victor O. Sadras \& Daniel Calderini (eds.). Crop Physiology: Applications for Genetic Improvement and Agronomy. Amsterdam, The Netherlands: Elsevier. p. 71-97.

Planton, S., Déqué, M., Chauvin, F. \& Terray, L. 2008. Expected impacts of climate change on extreme climate events. Comptes Rendus Geoscience 340: 564-574.

ProAgria, 2012. Tuottopehtoori. The ProAgria Advisory Centres, Vantaa. Cited 30 May 2012. Available online at http://www.proagria.fi/tuottopehtori/

Rajala, A., Hakala, K., Mäkelä, P. \& Peltonen-Sainio, P. 2011. Drought effect on grain number and grain weight at spike and spikelet level in six-row spring barley. Journal of Agronomy and Crop Science 197: 103-112.

Ramankutty, N., Foley, J.A., Norman, J. \& McSweeney, K. 2002. The global distribution of cultivable lands: current patterns and sensitivity to possible climate change. Global Ecology \& Biogeography 11: 377-392.

Rathke, G.-W., Christen, O. \& Diepenbrock, W. 2005. Effects of nitrogen source and rate on productivity and quality of winter oilseed rape (Brassica napus L.) grown in different crop rotations. Field Crops Research 94: 103-113.

Rathke, G.-W. \& Diepenbrock, W. 2006. Energy balance of winter oilseed rape (Brassica napus L.) cropping as related to nitrogen supply and preceding crop. European Journal of Agronomy 24: 35-44.

Reidsma, P. \& Ewert, F. 2008. Regional farm diversity can reduce vulnerability of food production to climate change. Ecology and Society 13: 38.

Reidsma, P., Ewert, F., Lansink, A.O. \& Leemans, R. 2010. Adaptation to climate change and climate variability in European agriculture: the importance of farm level responses. European Journal of Agronomy 32: 91-102.

Roukola, A.-L. \& Vestberg, M. 1978. Fungus diseases of field bean in Finland during 1975-1977. Journal of the Scientific Agricultural Society of Finland 50: 455-467.

Salinari, F., Giosue, S., Tubiello, F.N., Rettori, A., Rossi, V., Spanna, F., Rosenzweig, C. \& Gullino, M.L. 2006. Downy mildew (Plasmopara viticola) epidemics on grapevine under climate change. Global Change Biology 12: 1299-1307.

Salvagiotti, F., Cassman, K.G., Specht, J.E., Walters, D.T., Weiss, A. \& Dobermann, A. 2008. Nitrogen uptake, fixation and response to fertilizer N in soybeans: A review. Field Crops Research 108: 1-13.

Schär, V., Vidale, P.L., Lüthi, D., Frei, C., Häberli, C., Liniger, M.A. \& Appenzeller, C. 2004. The role of increasing temperature variability in European summer heatwaves. Nature 427: 332-336.

Shahbaz, A.M., Oki, Y., Adachi, T., Murata, Y. \& Khan, M.H.R. 2006. Phosphorus starvation induced root-mediated pH changes in solubilization and acquisition of sparingly soluble P sources and organic acids exudation by Brassica cultivars. Soil Science and Plant Nutrition 52: 623-633.

Sieling, K. \& Kage, H. 2006. N balance as an indicator of N leaching in an oilseed rape - winter wheat - winter barley rotation. Agriculture, Ecosystems and Environment 115: 261-269.

Smith, B.J., Kirkegaard, J.A. \& Howe, G.N. 2004. Impacts of Brassica break-crops on soil biology and yield of following wheat crops. Australian Journal of Agricultural Research 55: 1-11.

Stoddard, F., Hovinen, S., Kontturi, M., Lindström, K. \& Nykänen, A. 2009. Legumes in Finnish Agriculture: history, present status and future prospects. Agricultural and Food Science 18: 191-205.

Stoddard, F.L., Nicholas, A.H., Rubiales, D., Thomas, J. \& Villegas-Fernández, A-M. 2010. Integrated pest management in faba bean. Field Crops Research 115: 308-318.

Tike 2012. Agricultural statistics. Information Centre of the Ministry of Agriculture and Forestry, Tike, Helsinki.Cited 30 May 2012. Available online at http:// www.matilda.fi

Trnka, M., Olesen, J.E., Kersebaum, K.C., Skjelvåg, A.O., Eitzinger, J., Seguin, B., Peltonen-Sainio, P., Rötter, R., Iglesias, A., Orlandini, S., Dubrovský, M., Hlavinka, P., Balek, J., Eckersten, H., Cloppet, E., Calanca, P., Gobin, A., Vucetic V., Nejedlik, P., Kumar, S., Lalic, B., Mestre, A., Rossi, F., Kozyra, J., Alexamdrov, V., Semerádová, D. \& Zalud, Z. 2011. Agroclimatic conditions in Europe under climate change. Global Change Biology 17: 2298-2318.

USDA 2011. USDA agricultural projections report (OCE-2011-1). Long-term agricultural projection tables. Cited 30 May 2012. Available online at http://www.ers.usda.gov/briefing/projections

Venäläinen, A., Saku, S., Kilpeläinen, T., Jylhä, K., Tuomenvirta, H., Vajda, A., Ruosteenoja, K. \& Räisänen, J. 2007. Sään ääri-ilmiöistä Suomesta (The aspects about climate extremes in Finland). Finnish Meteorological Institute, Reports 2007:4, 81 p. Helsinki. (Abstract in English).

Westphal, C., Steffan-Dewenter, I. \& Tscharntke, T. 2009. Mass flowering oilseed rape improves early colony growth but not sexual reproduction of bumblebees. Journal of Applied Ecology 46: 187-193.

von Braun, J. 2009. Addressing the food crisis: governance, market functioning, and investment in public goods. Food Security 1: 9-15. Zoschke, A. \& Quadranti, M. 2002. Integrated weed management: Quo vadis? Weed Biology and Management 2: 1-10. 